Chicago-Kent College of Law

Scholarly Commons @ IIT Chicago-Kent College of Law

January 2011

\title{
Homogenous Rules for Heterogeneous Families: The Standardization of Family Law When There is No Standard Family
}

Katharine K. Baker

IIT Chicago-Kent College of Law, kbaker@kentlaw.iit.edu

Follow this and additional works at: https://scholarship.kentlaw.iit.edu/fac_schol

Part of the Family Law Commons

\section{Recommended Citation}

Katharine K. Baker, Homogenous Rules for Heterogeneous Families: The Standardization of Family Law When There is No Standard Family, (2011).

Available at: https://scholarship.kentlaw.iit.edu/fac_schol/55

This Article is brought to you for free and open access by the Faculty Scholarship at Scholarly Commons @ IIT Chicago-Kent College of Law. It has been accepted for inclusion in All Faculty Scholarship by an authorized administrator of Scholarly Commons @ IIT Chicago-Kent College of Law. For more information, please contact jwenger@kentlaw.iit.edu, ebarney@kentlaw.iit.edu. 
DRAFT - Please do not cite

or quote without permission

\title{
HOMOGENOUS RULES FOR HETEROGENEOUS F AMILIES: THE STANDARDIZATION OF FAMILY LAW WHEN THERE IS NO STANDARD FAMILY
}

\begin{abstract}
Katharine K. Baker ${ }^{*}$
"The demographic changes of the past century make it difficult to speak of an average American family. The composition of families varies greatly from household to household."
\end{abstract}

Troxel v. Granville, 530 U.S. 57, 63 (2000)

As Justice O’Connor suggested a decade ago, there may not be a typical American family. But there are, increasingly, typical family law obligations. As the marital nuclear family diminishes in prevalence and as academic calls for a more fluid, contextual legal understanding of family grow by the day, the law of family obligation is moving in the opposite direction. The obligations the law imposes on one because one is a family member are becoming increasingly formulaic, uniform and status-based, even while functional and intellectual forces would seem to be pulling the law in the opposite direction.

This article explores the law of family obligations: child support, property distribution, and alimony. These obligations are imposed primarily upon what we think of as family dissolution, but they help express the legal meanings of parenthood and marriage for all. ${ }^{1}$ In particular, they illuminate how the law constructs parental and

\footnotetext{
* Professor of Law, Chicago-Kent College of Law. I would like to thank Susan Appleton, Naomi Cahn and June Carbone for very helpful comments.

${ }^{1}$ As discussed infra text accompanying notes 61-69, child support is often imposed not only when the family dissolves, but when it starts, at the birth of a child. Property division and alimony adjudications come only in the event of divorce.
} 


\section{Homogeneous Rules}

marital commitments. One might think that these legal meanings would help shape the social meanings of parenthood and marriage, just as evolving social understandings of family would influence the development of the law. But there is a striking dissonance between how the law is shaping the meaning of family and how people seem to assume the meaning of family is changing.

Much recent family law scholarship, reflecting the reality of new family forms, extols the virtues of a more expansive, contextual legal understanding of family. The contemporary adjudication of family obligations, on the other hand, suggests a stark resistance to contextual evaluation of commitments. Among those who live and work in the world of family law obligation, there is a yearning for predictability and efficiency. Context is expensive and invasive. The social changes that have generated the calls for more attention to context include greater diversity in family form and more acceptance of that diversity by the general public. But the more varied the potential family forms, the more expensive and invasive a law that evaluates context becomes. Effective legal enforcement of family obligation may require legal definitions of family that inevitably impede expansive, contextual understandings of family.

This article argues that despite the profoundly limited way in which the current law identifies families, some reliance on restricted legal definitions of family will be necessary for any meaningful system of family obligation to operate. While demonstrating how arbitrary most of the rules surrounding family definition and obligation are, the article defends that arbitrariness in general, if not in its particulars, as being a legitimate and likely non-controversial means of ensuring efficient determination 


\section{HOMOGENEOUS RULES}

of obligation. A system with a much less limited understanding of family would likely be a system with much less enforceable family obligation.

The argument proceeds as follows. Part I provides a summary of the demographic changes to the family during the last 40 years, with a brief overview of some of the academic response to those changes. Most of the scholarship seems to implore the law to either recognize more kinds of families or to cease recognizing (and thereby privileging) any family forms. Part II describes the changes to the law of family obligation during the period in which the demographics of family life changed. Forty years ago, context and discretion were everywhere in the law of family obligation. Today, it is common to see statutes consisting of little more than econometric formulas or percentages that calculate obligation. Part III delves more deeply into those formulas.

By unpacking the formulas, one sees that family law has turned to algorithms not because reformers have come to agreement about the origins and scope of family law obligation but because they have not. The formulas are riddled with arbitrary and contested conclusions about who should be obligated and for how much. But once those conclusions have been incorporated into a formula, they help create their own sense of fairness: At least formulae render predictable results.

Part IV offers a defense of the formulaic arbitrariness and suggests that there is a causal connection between increasingly heterogeneous family forms and homogenous legal obligations. Ever fluctuating family forms make the need for practical, enforceable obligation determinations more urgent. ${ }^{2}$ Intuitive understandings of abstract obligation coupled with controversial concepts of why obligation should be triggered and in what

\footnotetext{
${ }^{2}$ For instance, when living apart from one's children becomes more common, child support enforcement becomes an important issue for many more households. When couples split up more often, property distribution rules seem more salient to many people's lives. See infra Part IV.
} 


\section{HOMOGENEOUS RULES}

amounts have led to a compromise of sorts. Because reformers cannot agree on principles that will lead to fair outcomes in the majority of cases, they have settled for rules that can lead to consistent and efficient outcomes in the majority of cases.

Part V situates the analysis of family law obligation in the contemporary academic debates concerning the state’s role in conferring family status. First, it highlights how the embrace of formulas indicates a willingness to cede considerable authority to the state. For the formulas to work, there need to be readily ascertainable legal definitions of family. The state provides those definitions. Recognizing the primacy of the state's role in defining obligation has opposite implications for different constitutional claims to family. It undermines fundamental rights claims to marriage and parenthood, while strengthening equality claims to those same family statuses. In light of those findings, the article then questions whether contemporary academic calls to diminish the importance of family status run the risk of diminishing the existence of family obligation. Part VI concludes.

\section{The Destandardization of the Family}

Just ten years after Justice O’Connor suggested that there was no longer an average American family, her words have become almost cliché. No one seems surprised by the numbers anymore. Traditional nuclear families, defined as heterosexual married couples living with their own children, make up less than $1 / 4$ of all households in the United States. $^{3}$ By 2008, more than $40 \%$ of all newborns were born to unmarried

\footnotetext{
${ }^{3}$ Jason Fields, America's Families and Living Arrangements: 2003 at 2 (US Census Bureau 2003) (down from $40 \%$ in 1970).
} 


\section{HoMOgENEOUS RULES}

women. ${ }^{4} 40 \%$ of all single mothers never marry. ${ }^{5}$ One third of adults (and $40 \%$ of adults under age 50) have cohabited with someone without being married. ${ }^{6}$ One in six children are born to a cohabiting couple and one half of those children will have had their parents separate by the time they are 9 years old. ${ }^{7}$

The divorce rate hovers at $50 \%$ of all marriages. It is slightly lower among whites (47\% ), but significantly higher among African-Americans (70\%). ${ }^{8}$ Of children born to married parents, $25 \%$ will have their parents divorce by the time they are 9 years old. ${ }^{9}$ Children with cohabiting parents are more likely than children of divorced parents to find their custodial parent in a new cohabiting relationship within a few years of the breakup, ${ }^{10}$ but children of divorced parents are still likely to experience a new family. Fiftyfour percent of divorced women remarry within five years of divorce and 75\% of divorced women remarry within 10 years. ${ }^{11}$

Reproductive technology and gay rights have also upended traditional understandings of family. Genetic material and reproductive labor can now be purchased in open markets by men and women. Gay men and lesbians can marry in 5 states ${ }^{12}$ and

\footnotetext{
${ }^{4}$ Gretchen Livingston and D’Vera Cohn, The New Demography of American Motherhood, Social and Demographic Trends Project, Pew Research Center, May 6, 2010.

${ }^{5}$ Paul Taylor, Cary Funk and April Clark, As Marriage and Parenthood Drift Apart, Public Is concerned about Social Impact, at 61 (Pew Research Center 2007) 30 [Hereinafter Marriage and Parenthood]

6 Marriage and Parenthood, supra note 5 at. 3

${ }^{7}$ Andrew Cherlin, The Marriage-Go-Round: The State of MARriage And the FAmily in America TODAY 164 (Random House 2009).

${ }^{8} \mathrm{Id}$. at 170 .

${ }^{9} \mathrm{Id}$.

${ }^{10}$ Id. at 164. The typical parent who has several intimate partners while raising her children is a white female high school graduate. African-American women are more likely to have children without as many partners. Latinas are less likely than whites to have as many break-ups. Id.

${ }^{11}$ CDC, Cohabitation, Marriage, Divorce and Remarriage in the United States, July 2003.

12 Massachusetts, Vermont, Connecticut, Iowa, and New Hampshire allow same sex couples to marry, as does the District of Columbia.
} 


\section{HOMOGENEOUS RULES}

enter into the legal equivalence of marriage in several others. ${ }^{13}$ Gay couples openly parent children together. Most states allow gay individuals to adopt and many allow a gay man or lesbian woman to adopt his or her partner's child. ${ }^{14}$

Then there are the economic and gender changes. In 1970, only 4\% of wives earned more than their husbands. By 2007, 22\% of wives out-earned their husbands. ${ }^{15}$ Approximately $70 \%$ of mothers with children under age 18 work outside the home and $65 \%$ of married mothers work outside the home. ${ }^{16}$ More than $50 \%$ of college graduates today are women. ${ }^{17}$ In 1970, 37\% of college educated husbands had college-educated wives. By 2007, that percentage had leaped to $71 \%$. In 1970 , no more than $1 \%$ of business, law or medical students were women. ${ }^{18}$ Today, $49 \%$ of medical students are women, ${ }^{19} 47 \%$ of law students are women ${ }^{20}$ and $37 \%$ of business school students (MBAs) are women. $^{21}$

For the most part, people accept the legitimacy of these changing demographics. ${ }^{22}$ Women's access to higher education and equal employment opportunities are thoroughly

\footnotetext{
${ }^{13}$ New Jersey, California and Illinois offer gay and lesbian couples all of the legal incidents of marriage, but not the name marriage.

${ }^{14}$ Gary J. Gates, M.V. Lee Badgett, Jennifer Macomber, Kate Chambers, Adoption and Foster Care by Gay and Lesbian Parents in the United States, at 3, The Williams Institute at UCLA School of Law, March 2007; Human Rights Campaign, Parenting Laws: Second Parent Adoption, http://www.hrc.org, updated April 10, 2010.

${ }^{15}$ Paul Taylor, Richard Fry, D’Vera Cohn, Wendy Want, Gabriel Velasco, Daniel Dockterman, Women, Men and the New Economics of Marriage, (Pew Research Center, 2010) [Hereinafter New Economics]

${ }^{16}$ U.S .DEPT. OF LAB BUREAU OF LAB StATISTICS, NEWS, EMPLOYMENT CHARACTERISTICS OF FAMILIES IN 2005, tbl 45 (April 27, 2006) Oct. 182006

${ }^{17}$ Id. (53.5\% of college graduates are women).

${ }^{18}$ NaOmi Cahn And June Carbone. Red Families v. Blue Families: Legal Polarization AND the Creation of Culture 79 (Oxford University Press 2010).

19 Association of American Medical Colleges, Women in US Academic Medicine: Statistics and Benchmarking Report 2008-2009 at 12.

${ }^{20}$ ABA Legal Education Pages, Enrollment and Degrees Awarded 1008-09, at 1.

${ }^{21}$ The Association to Advance Collegiate Schools of Business, Business School Data Trends and 2010 List of Accredited Schools at 24.

${ }^{22}$ The one change that the majority of Americans has the hardest time accepting is the prevalence of unmarried motherhood. 66\% of Americans think that single women having children is a bad thing for society. Marriage and Parenthood, supra note 5 at 5.
} 


\section{HOMOGENEOUS RULES}

non-controversial. So, mostly, is divorce and cohabitation. $67 \%$ of the public believes that if parents are very unhappy, their children are better off having them divorce. 58\% of the public believes that divorce is preferable to maintaining an unhappy marriage. ${ }^{23}$ $60 \%$ believe that premarital sex is acceptable. ${ }^{24} 53 \%$ condone living together without getting married. ${ }^{25} 55 \%$ favor allowing gay men and lesbians to enter into some form of legal relationship that would afford them the same rights as married couples. ${ }^{26}$

Given these demographic changes, the academic calls for more flexible, inclusive understandings of parenthood and familial partnership are not particularly surprising. With so much parenting happening outside of the conventional nuclear family, numerous scholars have called for an expanded understanding of parenthood, one that looks at functional relationships, ${ }^{27}$ and/or caretaking networks, ${ }^{28}$ and/or intent-to-parent. ${ }^{29}$ Some scholars see changing demographics and technology as necessitating less attention be paid to biology as a basis for parenthood. ${ }^{30}$ Some suggest that perhaps more attention should be paid to biology. ${ }^{31}$ Many urge courts to embrace the idea of multiple

\footnotetext{
${ }^{23}$ Id at 61.

${ }^{24} \mathrm{Id}$. at 55.

${ }^{25}$ Id. at 57.

${ }^{26}$ Id. at 65.

${ }^{27}$ Martha Minnow, Redefining Families: Who's In and Who's Out, 62 CoLO. L REv 269, 270-72 (1991); Barbara Woodhouse, It All Depends on What You Mean by Home, 1996 UTAH L REv 569, 576-84; Nancy D. Polikoff, This Child Does Have Two Mommies: Redefining Parenthood to Meet the Needs of Children in Lesbian-Mother and Other Non-Traditional Families, 78 GEO L J 459 (1990).

${ }^{28}$ Melissa Murray, The Networked Family: Reframing the Legal Understanding of Caregiving and Caregivers, 94 VA L REV 385 (2008).

${ }^{29}$ Katharine K. Baker, Bargaining or Biology? The History and Future of Paternity Law and Parental Status, 14 Cornell J. L. \& PuB. Pol'y 1, 26 (Fall 2004); Susan Appleton. Presuming Women: Revisiting the Presumption of Legitimacy in the Same-Sex Couples Era, 86 B.U. L. REV. 227, 276 (2006).

${ }^{30}$ MARTHA Fineman, The NEUTERED FAMiLy (1996) (arguing that the legal family should be understood as centered around a binary caretaker/child dyad not a sexualized adult relationship that might produce children); Baker, supra note 29, at 48, (suggesting that a woman should have all of the parental rights at birth, absent an agreement indicating an intent to share).

${ }^{31}$ Annette Appel, Controlling for Kin: Ghosts in the Postmodern Family (suggesting that children experience biological connection as an important part of identity and therefore the law should be careful not to exclude birth mothers or genetic donors from definitions of family) (WASH UNIV. FACULTY PUB. SERIES)
} 


\section{HOMOGENEOUS RULES}

parenthood. ${ }^{32}$ Others argue that perhaps the law should limit the number of parents to one. $^{33}$

There have been comparable calls for the restructuring of marriage and sexual relationships. Many commentators bemoan the narrow, stifling manner in which the legal recognition of marriage regulates adult intimacy. ${ }^{34}$ Given the deregulation - and constitutional protection - of most consensual adult sexual activity, ${ }^{35}$ the idea of steering people toward monogamous, long-term relationships seems anachronistic and pointless to some. ${ }^{36}$ In the midst of the same-sex marriage debate, numerous articles have questioned state involvement in marriage at all. ${ }^{37}$ One scholar has suggested that the law should allow each individual to distribute the various benefits of marriage to a wide variety of other adults, so that the law might better capture the importance of friendship. ${ }^{38}$ Others have suggested that private ordering, or some form of partnership contract, should replace marriage as the paradigm to govern intimate relationship because private contracts could better incorporate the diversity of relationships that actually exist. ${ }^{39}$ Still others have suggested that perhaps the law's relationship to family should be as its relationship to

\footnotetext{
${ }^{32}$ Melanie Jacobs, Why Just Two? Disaggregating Traditional Parental Rights and Responsibilities to Recognize Multiple Parents, 9 J. L. \& FAM STUD 309 (2007); Laura Kessler, Community Parenting, 24 WASH UNIV. J L \& POL’Y 47 (2007).

${ }^{33}$ Fineman, supra, note 29.

${ }^{34}$ Katherine Franke, Sexuality and Marriage: The Politics of Same Sex Marriage Politics, 15 Colum. J. GENDER \& L. 236, 239-240 (2006) (depicting gay couples as “normal” is boring); MiCHAEL WARNER, THE TROUBLE WiTH NORMAL 787-95 (celebrating diversity in sexual practices and criticizing attempts to channel intimate behavior).

${ }^{35}$ Eisenstadt v. Baird, 405 U.S. 438 (1972); Lawrence v. Texas, 539 U.S. 558 (2003).

${ }^{36}$ Laura Rosenbury, Friends with Benefits, 106 Mich L REV 189 (2007); Rachel Moran, How Second-Wave Feminist Forgot the Single Woman, 33 HOFSTRA L REV 223 (2004).

${ }^{37}$ See Edward Zelinisky, Deregulating Marriage: The Pro-Marriage Case for Abolishing Civil Marriage and Daniel Crane, A Judeo-Christian Argument for Privatizing Marriage, 27 CARD. L REV 1161 and 1221 (2006) (both advocating the abolition of civil marriage).

${ }^{38}$ Rosenbury, supra note 36 at 221.

${ }^{39}$ Martha Ertman, Reconstructing Marriage: An InterSEXional Approach, 75 Den. UnIV. L. Rev. 1215, 1216 (1998).
} 


\section{HOMOGENEOUS RULES}

religion. That is, the state could not establish any normative family, though it could recognize those in existence. ${ }^{40}$

The vast majority of this scholarship has focused on how individuals benefit when the state recognizes their relationships as familial. For instance, a non-traditional parent who is recognized as a legal parent could receive some sort of right to visitation or custody and possibly some sort of right to decision-making on behalf of a child. A nontraditional parent could also be eligible for FMLA leave or other workplace discrimination protection. ${ }^{41}$ A non-traditional intimate partner who is recognized as a kind of spouse could receive intestacy rights, special tax treatment and rights to own forms of property in common. There are many advantages to being recognized legally as a family member.

There are also obligations that accompany family status, however. Much less of the scholarship has been devoted to this. If one does secure the right to visit a child with whom one has developed a parent-like or significant caretaking relationship, should one also be held responsible for child support? If one secures the right to FMLA protection in order to take care of a sick child, does one have the same legal obligations a parent does to care for that child after the illness? If the state significantly de-regulates or exits the marriage business altogether, would financial obligations develop between parties that shared an intimate or interdependent relationship? If we end marriage as the law has construed it, how would we know what relationship norms should be used to inform the content of any implicit or explicit financial agreement? Is there such thing as a family

\footnotetext{
${ }^{40}$ Alice Ristroph and Melissa Murray, Disestablishing the Family, 119 YALE L J 101, 135 (2010).

${ }^{41}$ The Family Medical Leave Act, 29 USC § 2601 et seq. ("FMLA”) requires employers to provide up to 12 weeks of unpaid parental leave to caretakers and prohibits employers from discriminating on the basis of parental status.
} 


\section{HOMOGENEOUS RULES}

relationship that does not include obligation? Answers to these questions require some sort of consensus on why and how legally enforced family obligations should arise. The analysis that follows reveals just how lacking that consensus may be.

\section{The Standardization of Family Law Obligation}

The typical domestic relations attorney spends most of his or her time considering what obligations family members owe each other. There are three standard family law obligations, one, child support, attaching to parental status, and two, property distribution and alimony, attaching to marital status.

1. Child support

\section{a. History}

Blackstone wrote that parents have a duty to support their children, ${ }^{42}$ but until well into the nineteenth century, in this country, only unwed fathers of low income children were subject to legal proceedings for child support. ${ }^{43}$ Following in the tradition of the British Poor Laws, which allowed localities to recoup aid expended on children from the unwed fathers of those children, states in this country allowed governmental agencies to sue unwed fathers of children on aid. ${ }^{44}$ Unwed fathers of children who were being supported privately originally had no legal obligation to support their children. Gradually, in England and in most of the United States, child support obligation came to

\footnotetext{
421 BLACKSTONE, COMMENTARIES ON THE LAWS OF ENGLAND 446-54 (Christian ed. 1807) Blackstone considered the parental support to be a moral one though, not a legal one. Id.

${ }^{43}$ I use the term "unwed fathers" to refer to men who were not married to the mother at the time of the child's birth.

${ }^{44}$ Donna Schuele, Origins and Development of the Law of Parental Child Support, 27 J. FAM. L. 807 at 5 (1988-1989).
} 


\section{HOMOGENEOUS RULES}

attach to all unwed fathers, ${ }^{45}$ but the enforcement of child support obligations against unwed fathers varied tremendously well into the twentieth century.

In some states the duty to support derived from criminal liability in bastardy or fornication. ${ }^{46}$ Some states only imposed parental obligation on unwed fathers who voluntarily acknowledged paternity. ${ }^{47}$ At least one state developed a separate code setting a separate defined amount of support owed by the father of an illegitimate child. ${ }^{48}$ It was not until 1972 that Texas and Idaho were willing to impose any child support obligation on unwed fathers.

The plight of divorced fathers was different. Until the mid-nineteenth century, divorcing fathers received custody of their children so child support was not an issue. The support duty followed the custody. ${ }^{49}$ As the nineteenth century progressed, courts began to afford mothers custody, though only if mothers could prove they (or their families) could adequately support the child. ${ }^{50}$ Once mothers began receiving custody more regularly, maternal custody became the norm and the idea that a divorced non-custodial parent might have a duty to support his child emerged as salient. What probably swayed courts most toward holding noncustodial fathers responsible for some measure of child

\footnotetext{
${ }^{45}$ In England, unwed finally mothers secured the right to sue the father of a child for child support, regardless of whether the child was receiving state aid, in 1844. LAWRENCE P. HAMPTON, DisPUTED PATERNITY PROCEEDINGS, sec. 1.02(1)-(3)

${ }^{46}$ Harry D Krause, Illegitimacy: LaW ANd Social Policy at 109 (1971).

${ }^{47}$ See VA CODE ANN Sec. 20-61 (1950)

${ }^{48}$ FLA STAT ANN SeC 48-7-4 (1966).

${ }^{49}$ See Leslie Harris, Dennis Waldrop and Lori Waldrop, Making and Breaking Connections Between Parents' Duty to Support and Right to Control Their Children, 69 OR. L. Rev. 689 (1990). Some state courts, following Blackstone, held that the parental duty to support was a moral one that could not be legally enforced. See BLACKSTONE, supra note 42.Other state courts held that parents were legally responsible for supporting their children, but that duty was derivative of the parent's right to control their children, including their children's labor. See Harris, Waldrop and Waldrop, supra at 690. Because fathers were presumptively entitled to custody and control, see Schuele, supra note 44 at 2, there was little need for one parent to ever ask a court to enforce a duty of parental support against another.

${ }^{50}$ Schuele, supra note 44 at 2.
} 


\section{HOMOGENEOUS RULES}

support was the judgment of marital fault. ${ }^{51}$ Mothers successfully argued that a father should not be able to use his own culpable marital behavior as an excuse for not supporting his children. Thus, where mothers could prove that that the husband's behavior was responsible for marital breakdown, courts were more likely to hold fathers responsible for some specific amount of child support. ${ }^{52}$

By the late nineteenth century, most state divorce codes gave courts authority to hold noncustodial parents responsible for child support to an ex-spouse, but those statutes also gave courts wide discretion in whether and how to do so. ${ }^{53}$ Courts often labeled the divorce award "alimony” without signifying what portion was meant as spousal support and what was meant as child support. ${ }^{54}$ If the award was high enough, reviewing courts would presume it was meant to include care for children. ${ }^{55}$ With so little consensus on why fathers should be responsible for child support and with so much variation in the degree of culpability different fathers might be thought to have for marital break-up, it is hardly surprising that child support awards varied so tremendously.

b. Reform

\footnotetext{
${ }^{51} I d$. at 5. See id. at 9.

${ }^{53}$ VeRnier, AMERICAN FAMILY LAWS Vol 2, §95 at 192 (1936).

${ }^{54}$ Schuele, supra note 44 at 7.

${ }^{55} \mathrm{Id}$.
}

${ }^{52}$ Enforcing this duty was still exceedingly difficult, however. Courts were barred from ordering payments into the future so mothers could only bring actions for past support not paid. And when mothers did that, they were barred from statutes of limitations from arguing for more arrearages that had accumulated over the course of many years. For the most part, mothers simply did not bring these actions. If obligors were delinquent, there was not much obligees could do. The important point is that by the mid- nineteenth century courts were willing to conceptualize a child support duty for a non-custodial parent. But if that duty could not be discharged in a lump sum payment at the time of divorce, it might never be collected. 


\section{HOMOGENEOUS RULES}

As divorce rates rose - which they did continually from the mid nineteenth century until the late $1970 s^{56}$ - child support law became ever more important. New theories of child well-being encouraged judges to make custody determinations more child-centered. The "best interest of the child" standard replaced the maternal preference standard for custody. ${ }^{57}$ The need to think about the particularities of the child for custody purposes probably led courts to be more careful in distinguishing between child support and alimony. ${ }^{58}$ Children's needs began to be viewed as paramount.

The 1970s also saw an almost complete overhaul of divorce law nationwide. Marriage was no longer conceptualized as permanent; both men and women were expected to be able to take care of their own needs; blame was supposed to be banished from the marital dissolution discourse. As will be discussed more fully below, these theoretical changes in the basic legal understanding of marriage required fundamental changes in the law of marital obligation. No-fault divorce became available almost everywhere. Statutes regarding property distribution and alimony were altered to try to reflect a more modern version of marriage and divorce. Alimony was discouraged.

Not much changed with regard to child support though. Most statutes continued to give judges wide discretion to award whatever child support amount they saw fit. The statutes suggested that the judges consider the needs of the child and the wealth of the

\footnotetext{
${ }^{56}$ ElLman, KuRTZ, SCOTt, EITHORN AND Bix. FAMILy LAW: CASES AND MATERIALS, at 234-35 (4th ed., Lexis Nexis 2004) (hereinafter ElLMAN, KURTZ) (graph showing proportion of marriage entered that end in divorce by year, starting in 1867 and ending in 1985).

${ }^{57}$ Leslie Harris, Lee Teitlelbaum, June Carbone, Family Law, at 585 (4th ed., Aspen Publishers 2010) (hereinafter HARRIS, TEITELBAUM, CARBONE) .

${ }^{58}$ Since at least the mid $20^{\text {th }}$ century there has also been notorious interplay between alimony and child support for tax reasons. Because alimony is tax deductible and child support is not, separating parties had every incentive to label to bulk of any settlement alimony, not child support. The IRS designed rules to curb this practice, but it probably still continues. See HARRIS, TEITELBAUM AND CARBONE, supra note 57 at 569.
} 


\section{HOMOGENEOUS RULES}

parents and the marital standard of living, but there was little guidance beyond that and awards varied tremendously. ${ }^{59}$

It was the federal government, not family law judges or state code drafters, that finally put some limits on discretionary child support awards. Congress, like the drafters of the British Poor Laws centuries before, was concerned about securing more private funds for low income children so that those children would be less of a financial burden on the government. Using the spending power, Congress passed The Federal Child Support Act of 1984, which required all states to draft specific guidelines for child support purposes, ${ }^{60}$ and The Family Support Act of 1988, which required that those guidelines create a rebuttable presumption of obligation. ${ }^{61}$ The federal regulations interpreting those Acts, which have been in place since 1989, require states to use “numeric guidelines" that take into account "all earnings of and income of the noncustodial parent” and "economic data on the cost of raising children."62 As one of the leading casebooks in family law comments, the term "guideline” is a misnomer. “'Formulas'” and 'tables,' along with many presumptive rules, are more accurate descriptions of the numeric algorithms that now govern child support. ${ }^{63}$

None of the formulas actually use what the statute explicitly requires, "economic data on the cost of raising children," for two reasons. First, there is no economic data on cost. No one has ever collected it. Second, and related to the first, cost data would require quintessentially subjective value judgments. In order to determine the cost of an

\footnotetext{
${ }^{59}$ Nancy Thoennes et al., The Impact of Child-Support Guidelines on Award Adequacy, Award Availability and Case Processing Efficiency, 25 FAM. L. Q. 325, 326 (1991) (citing studies).

${ }^{60} 42$ USC $\S \S 666-667$ (2000).

${ }^{61}$ Pub. L. 100-485, 42 USC §667(b) (2000).

6245 CFR $§ 302.56(\mathrm{c})(\mathrm{l})$,(h).

${ }^{63}$ See Ellman, KuRTZ, supra note 56 at 460.
} 


\section{HOMOGENEOUS RULES}

expense, one needs to define the contours of the expense, so as to include in the cost figure everything that goes into that expense. If the expense is defined as "raising a child," the determination of cost cannot be determined neutrally. What kind and how much food, clothing, enrichment, education and recreation does a child need, deserve or benefit from? Millions of different parents answer those questions differently every day.

The guidelines rely instead on expenditure data. The expenditure data tries to capture average marginal expenditures on children at different income levels. How much does the average two-parent household that earns $\$ 20,000$ annually spend on one child? How much does that household spend on two children? How much does the average two-parent household that earns $\$ 60,000$ spend on one child, two children etc. To derive the expenditure data, economists use equivalence scales that measure standards of living based on adult expenditures. For instance, if a childless couple earning $\$ 60,000$ a year spends the same amount on adult goods as a two child family earning $\$ 90,000$ a year, the equivalence scale suggests that the marginal cost of two children at the $\$ 90,000$ income level is $\$ 30,000 .{ }^{64}$ Guidelines are designed to reflect those marginal costs at different income levels. The goal is for the custodial household to be able to spend the same amount on children that it would spend if the parents lived together. ${ }^{65}$

Most states currently use one of two formulas to determine parental obligation with this data. The majority of states use the "income shares" model, which combines the two parents' incomes, looks to the marginal expenditure figure for that income level, and then divides responsibility for that amount between the parents in proportion to their total contribution to the joint income figure. For instance, a non-custodial parent would

\footnotetext{
${ }^{64}$ Ira Ellman, Fudging Failure: The Economic Analysis Used to Construct Child Support Guidelines, 2004 U CHI L FORUM 167, 190.

${ }^{65}$ There are numerous problems with the expenditure figure that will be addressed in Part III.
} 


\section{HOMOGENEOUS RULES}

pay the custodial parent half of the marginal expenditure amount for their income level if both parents earned the same amount. A non-custodial sole earner parent would pay the entire marginal expenditure amount. Approximately 19 states use the "percentage of obligor income” (“POOI”) formula. Under this approach, the obligor pays a percentage of his income based on the number of children at issue (20\% for one child, $25 \%$ for two children etc.) The formula bases the percentages on the same marginal expenditure data so the awards are often comparable. ${ }^{66}$

As Part III will detail, there are numerous theoretical problems with these formulas and though seemingly neutral, they are packed with value judgments about which there is likely significant disagreement. But the guidelines are remarkably non-

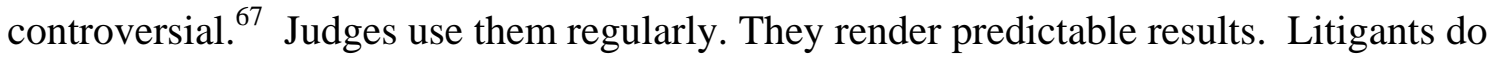
not challenge them. Whether in mediation or pre-litigation, settling parties routinely agree on child support amounts that are consistent with the guidelines. ${ }^{68}$ The guidelines apply to anyone who is considered a parent. ${ }^{69}$

\section{Property Division}

\section{a. History}

\footnotetext{
${ }^{66}$ As an example, assume that each parent makes $\$ 50,000$ a year and the marginal child expenditure figure for a child in a $\$ 100,000$ household is $\$ 20,000$. Under an income shares formula, because the obligor earns $50 \%$ of the total parental income, he would pay $50 \%$ of the marginal expenditure figure, or $\$ 10,000$. Under a POOI formula, the obligor would pay $20 \%$ of his income, or (again), \$10,000.

67 The ALI Principles have proposed new guidelines that build on the old ones, but the ALI's proposal ignores many of the deepest theoretical flaws with the guideline structure. AMERICAN LAW INSTITUTE, PRINCIPLES OF THE LAW OF FAMILY DiSSOLUTION: ANALYSIS AND RECOMMENDATIONS $§ 3.06$ - 3.16 (2002) (hereinafter ALI PRINCIPLES) and infra Part IIIA.

${ }^{68}$ M. Marcus, W Marcus, N Stilwell and N Doherty, To Mediate or Not To Mediate: Financial Outcomes in Mediated Versus Adversarial Divorces, 17 MEDIATION QUARTERLY 143-151 (1999) (No significant difference in litigated versus mediated divorces.)

${ }^{69}$ At high income levels, courts sometimes stray from the guidelines on the theory that no child needs $23 \%$ of a very, very wealthy parent's yearly income, but departure from the guidelines at high income levels has also been criticized soundly criticized. See Larua Raajtes, High-Income Child Support Guidelines:

Harmonizing the Need for Limits with the Best Interest of the Child, 86 Chi.-Kent L. Rev. 317 (2011).
} 


\section{HOMOGENEOUS RULES}

Property distribution rules apply whenever a married couple gets divorced. Unlike the law of child support, the traditional law of property division was not tremendously discretionary. In community property states (8 states, mostly in the American West, that adopted continental European traditions), ${ }^{70}$ husband and wife were perceived as joint owners of all marital property. ${ }^{71}$ At divorce, marital property was divided between the parties. $^{72}$ Most community property states had very limited, if any, alimony provisions. An ex-wife's post-divorce needs were to be met, to the extent they could be met, by her property allocation and her property allocation was set at one half of the marital estate.

The idea of marital property was an anathema in most of the United States, however. The majority of states in the United States adopted the English common law system of title. ${ }^{73}$ At divorce, whoever had title to property received the property. ${ }^{74}$ This too was a bright line rule, and could be very harsh on divorcing women. At divorce, married women could receive only the property that they brought into the marriage though if a husband had squandered the property during the marriage, the wife had little remedy. Married women were prohibited from owning property until the mid- $19^{\text {th }}$

\footnotetext{
${ }^{70}$ There are nine community property states now. They are Arizona, California, Idaho, Louisiana, Nevada, New Mexico, Texas, Washington and Wisconsin. Wisconsin was the latecomer to the regime, switching to community property laws in 1983.

${ }^{71}$ Property earned by either spouse was usually considered marital, but inheritances and property brought into the marriage usually was not considered marital.

${ }^{72}$ Community property states do not necessarily divide community property equally at divorce. Some states have provisions requiring an equal division of property, but most permit an equitable division. See Thomas Oldham, Divorce, SEPARAtion And the Distribution of Property, Distribution of Property, $\S 3.03[5]$.

${ }^{73}$ For an explanation of how the parallel property regimes originally developed in Europe, see Charles Donahue Jr., What Causes Fundamental Legal Ideas? Marital Property in England and France in the Thirteenth Century, 78 MiCH L REV 59 (1980) .

74 There was some variation across time. Southern states did not even recognize judicial divorce until after the Civil War. Most northern states initially only recognized divorce mensa et thoro, which technically means legal separation. It was in that system that the idea of alimony developed as support in a relationship that had not officially ended. Once the common law states started recognized complete divorce, most retained the system that had been used with divorce mensa et thoro, property went to the husband and support went to the wife.
} 


\section{HOMOGENEOUS RULES}

century and even after passage of the Married Women’s Property Acts, women rarely acquired anything other than inheritance during a marriage. ${ }^{75}$ At divorce, women were entitled to anything titled in their name, but there was usually very little titled in their name.

Courts in common law jurisdictions had authority to order support or alimony from a husband to a wife with little property, but there was little to no consensus on what that award should represent. The amounts varied tremendously and they were usually tied to the degree of culpability found in the divorcing husband. The wife was thought entitled to alimony because the husband was responsible for the marital dissolution.

\section{b. Reform}

The national movement to eliminate, or at least provide alternatives to, faultbased divorce started in earnest in the 1960s and had achieved tremendous success by the mid 1970s. All states but one enacted legislation providing for divorce in cases of “irreconcilable differences.”76 But by destroying fault-based divorce, reformers ${ }^{77}$ also destroyed much of the theory governing financial disentanglement at divorce in titlebased jurisdictions. In its stead, reformers adopted a system of “equitable distribution.” Borrowing the concept of marital property from the community property states, the new statutes instructed judges to treat property acquired during the marriage as "marital

\footnotetext{
75 HARRIS, TEITELBAUM AND CARBONE, supra ntoe 57 at 38-39.

${ }^{76}$ This is the standard statutory justification for allowing two people to divorce in the absence of fault. New York was a hold out state and only recently adopted no-fault divorce protocols. See Paterson Signs No-Fault Divorce Bill, nytimes.com/2010/08/16/nyregion/16divorce.html

77 The reformers during this period included lawyers, judges, academics and politicians. See J. Herbie DiFonzo, No-Fault Marital Dissolution: The Bitter Triumph of Naked Divorce, 31 SAN DiEGo L. REv. 519 (1994) (describing the assorted cast of characters that played a role in moving states toward no-fault divorce laws.)
} 


\section{HOMOGENEOUS RULES}

property" and to divide that property "equitably” between the divorcing spouses, regardless of who held title. ${ }^{78}$ Equitable jurisdiction statutes typically provided judges with a long list of factors that might be considered relevant to an equitable distribution of property. $^{79}$ It was at this point that the law of property distribution became wildly unpredictable.

The statutes provided for “equitable” distribution not “equal” distribution of assets in part to allow judges to distribute property in such a way as to effectuate a kind of lasting fairness between the parties. Judges were given discretion to determine what an "equitable" distribution of property should be. In theory this allowed judges to award more property to the spouse with less earning capacity as a way of trying to lessen the differential in post-divorce standard of living. But this rarely happened. Some judges maintained an allegiance to title-based rules, possibly because statutes often offered such a long list of often contradictory factors that judges were left with no guidance. Other judges just applied whichever factors seemed to them most compelling. ${ }^{80}$

Gradually, though, courts have reached consensus on an understanding of equitable. It means equal - usually. Over time, relying in part on norms from some community property states, in part on various theories of partnership and promise, but also just craving a baseline from which to operate, most states have developed

\footnotetext{
${ }^{78}$ A few common law states did not adopt a system of marital property and instead gave courts authority to consider all property, however and whenever acquired, in deciding on an equitable distribution. See UNIFORM MARRIAGE AND DivORCE ACT § 307. These states are known as "hotchpot" states because the judge can throw all property into the hotchpot and then divide it up.

${ }_{79}$ See i.e., Illinois Marriage and Divorce Act, 750 ILCS 5/503(d)(1)-(12) (listing 12 factors for courts to consider when distributing property).

${ }^{80}$ See Mary Ann Glendon, Family Law Reform in the 1980s, 44 LA L. REV 1553, 1556 (1984) (describing how equitable distribution system left divorcing litigants "in a lottery whose outcome greatly depend(ed) on the luck of the judicial draw.”).
} 


\section{HOMOGENEOUS RULES}

presumptions or starting points of a 50/50 split. Six states codify the 50/50 division presumption in their statute, but many, many more have adopted the rules judicially. ${ }^{81}$

How easy it is to depart from the 50/50 presumption may depend on how much is considered marital property. Those states willing to consider all property, however and whenever acquired, as subject to division, are more willing to deviate from the 50/50 presumption in order to award more at dissolution to the person who came into the marriage with significantly more property. But there is striking conformity around the idea that all property produced by marital labor, that is, the labor of either spouse during the marriage, should be split equally at divorce. The ALI Principles explicitly adopt this principle. $^{82}$

To be sure, there is still considerable squabbling about what counts as marital property. Marital labor can produce many forms of property that are difficult to value at the time of divorce (stock options, retirement accounts, disability awards, for instance). But what has emerged as a reliable constant is that the property that marital labor has produced should be divided equally. ${ }^{83}$ Some high-profile, high-end divorces suggest that at levels of extreme wealth, ${ }^{84}$ courts balk at a fully equal division, but other high-end

\footnotetext{
81 Arkansas, Indiana, New Hampshire, California, Louisiana and New Mexico have all codified the 50/50 presumption. Many other states use the 50/50 rule as either a presumption or a starting point. These include Indiana, Nevada, North Carolina Oregon, West Virginia, Wisconsin, Illinois, Delaware, Iowa, Maine, Montana and New Jersey. Empirical work suggests that still other courts use a 50-50 rule without any guidance telling them to do so. As Marsha Garrison has noted, "[j]udges thus appear to gravitate strongly toward an equal division norm even in states that have no statutory or case law preferring such an outcome.” Marsha Garrison, The Economic Consequences of Divorce: Would Adoption of the ALI Principles Imporve Current Outcomes? 8 DUKE J. GENDER L. \& POL'Y 119, 124 (2001).

${ }^{82}$ ALI PRINCIPLES, supra note 67 at $\$ 4.09$. ("[M]arital property and marital debts are divided at dissolution so that the spouses receive net shared equal in value, although not necessarily identical in kind.”)

${ }^{83}$ Suzanne Reynolds, The Relationship of Property Division and Alimony: The Division of Property to Address Need, 56 Fordham L Rev 827 (1988) (finding that most equitable division statutes result in approximately equal division of property).

${ }^{84}$ See Wendt v. Wendt, 706 A 2d 1021 (Conn. Super. Ct. 1996).
} 


\section{HOMOGENEOUS RULES}

cases suggest that judges have become fully comfortable with the idea of a 50/50 split. ${ }^{85}$

The more comfortable judges are with the equal divide, the more ordinary it becomes and the more the vast majority of divorcing parties, who never actually get to a courtroom, divide equally the property that either's marital labor has produced. ${ }^{86}$

\section{Alimony/Maintenance}

\section{a. History and Reform}

When marriages were meant to last forever and when they were only terminated because one person violated the marital bargain, the law understood what alimony was. It was the payment of an on-going obligation of support to the innocent spouse. Because the husband was the only spouse with a duty to support, he was the only one who could be charged with alimony. ${ }^{87}$ In the early days of marriage in this country, some courts even adopted a theory for determining the amount of alimony. Women entitled to alimony were entitled to their dower amount, or what they would have gotten had their husband died - roughly $1 / 3$ of the husband's property. ${ }^{88}$ If the husband was not at fault, the wifes’s chances of securing alimony were remote.

When fault was banished - or at least mostly banished ${ }^{89}$ - from the marital dissolution discourse, reformers struggled with a justification for alimony.

\footnotetext{
${ }^{85}$ Polsky v. Polsky, 2008 W L 5062805 (Ill. App. Dis. 2008) (affirming trial court's straight equal divide of couple's property).

${ }^{86}$ Marcus, Marcus, Stilwell and. Doherty, supra note 68 at 151 (1999) ("our results indicate that most financial outcomes of mediated versus adversarial divorce formats are not significantly different”).

${ }^{87}$ The Supreme Court struck down gendered alimony statutes in 1979, Orr v. Orr, 440 US 268 (1979). All states now have provisions for awarding alimony to either a man or woman.

88 June Carbone, Futility of Coherence, 4 J. L. \& FAM. STUD. 43, 46 (2002). It does not appear that the $1 / 3$ figure, or the theory underlying it, survived into the $20^{\text {th }}$ century. It certainly is not referenced by $20^{\text {th }}$ century courts.

${ }^{89}$ Many states that adopted no-fault divorce, retained fault-based provisions for parties that preferred to sue for fault. See Illinois Marriage and Dissolution of Marriage Act, 750 ILCS 5/401(a)(1). Moreover, fault or culpability determinations routinely find their way into judicial decisions, regardless of whether they are acknowledged as such. See Katharine B. Silbaugh, Money as Emotion in the Distribution of Wealth at Divorce, in RECONCEIVING THE FAMILY: CRITIQUE ON THE AMERICAN LAW INSTITUTES' PRINCIPLES
} 


\section{HOMOGENEOUS RULES}

Accompanying the move to no-fault were also (i) a growing belief that women should be able to provide for themselves and (ii) a desire to let the parties go their separate ways after divorce. Accordingly, many statutes, including the Uniform Marriage and Divorce

Act, favored the elimination of alimony altogether. ${ }^{90}$ For situations in which that seemed too harsh, most statutes gave courts the authority to award what a dependent spouse needed and/or what was necessary for her to rehabilitate herself to an appropriate level of self-sufficiency. ${ }^{91}$

The problems with both the need and rehabilitation standards soon became manifest. "Need," referred to in the abstract, gives judges no baseline. What is need to be determined in reference to? Few judges were willing to let previously middle-class divorced wives sink to just above the poverty level, but using alimony (or “maintenance," as it came to be called) to allow her to remain at the marital standard of living imposed too great a burden on the obligor. Both spouses could not maintain the same standard of living unless there was considerable unused excess generated during the marriage. Thus, judges were left to assess their own sense of need and the awards varied widely between the extremes of poverty and the marital standard of living. ${ }^{92}$

The rehabilitation standard suffered from a comparable problem. Even if an obligor spouse could be held responsible for paying for his ex-spouse to "rehabilitate" herself into self-sufficiency, what level of self-sufficiency is appropriate? For instance, a teacher who left the workforce to raise her children might be able to re-activate her

OF THE LAW OF FAMILY Dissolution, at 240 (Robin Fretwell Wilson ed., 2006) (hereinafter RECONCEIVING THE FAMILY); Carbone, supra note 88 at 55.

${ }^{90}$ Cynthia Starnes, Mothers as Suckers: Pity, Partnership, and Divorce Discourse, 90 Iowa L. Rev. 1513, 1539 (April, 2005).

${ }^{91}$ Katharine K. Baker, Contracting for Security: Paying Married Women What They've Earned, 55 U CHI L REV 1193, 1200 (1998).

${ }^{92}$ ELLMAN, KURTZ supra note 56 at 364 (describing variation) 


\section{HOMOGENEOUS RULES}

teacher's license, but if she was married to a doctor or lawyer, her standard of living after divorce would still fall substantially. Should that matter? Some judges said yes. Some said no. There was very little way to predict.

The empirical work done on alimony suggests that the reforms of the 1970s decreased the frequency of alimony awards, ${ }^{93}$ but judges soon grew wary of relying on either need or rehabilitation theories to award maintenance, particularly in long-term marriages. The results just seemed too punitive. The judicial desire to award more was bolstered by a cottage industry of scholarly commentary that strained to explain why courts should award more. ${ }^{94}$ Usually these theories suggested that alimony payments be based on some notion of marital contribution, ${ }^{95}$ foregone opportunities ${ }^{96}$ or partnership theory. ${ }^{97}$ Some scholars suggested that the post-divorce standards of living in the two households should be equal. ${ }^{98}$ By the 1990s, many courts were using some or all of these theories to give more generous alimony awards in long term marriages.

Still, all commentators would agree that alimony remains the least coherent and most discretionary area of family obligation. Compensating an ex-spouse for the contributions she made to the household makes sense, but the market value for those domestic services is often quite low and many household contributions (attending a

\footnotetext{
${ }^{93}$ Marsha Garrison, The Economics of Divorce: Changing Rules, Changing Results in DivorCE Reform AT the Crossroads, at 75, 84 (Sugarman and Kay, eds. 1991); How Do Judges Decide Divorce Cases, 74 N.C. L. REV. 401 (1996) (alimony only awarded in 15\% of all divorces).

${ }^{94}$ Ira Ellman, The Making of Family Law, 33 FAM. L.Q. 801, 810 (discussing the "burst of academic writing” about policy rationales for maintenance).

${ }^{95}$ HARRIS, TEITELBAUM, AND CARBONE, supra note 57 at 345 ( $5^{\text {th }}$ ed. 2010).

${ }^{96}$ Ira Ellman, A Theory of Alimony, 77 CAL. L. REV. 1, 17 (Jan. 1989).

${ }^{97}$ Starnes, supra note 90 at 108.

${ }^{98}$ This theory is fairly popular among academics concerned about the consistently gendered nature of household work, see JoAn WiLLIAMs, UnBENDING GENDER (2000), Jane Rutherford, Duty in Divorce: Shared Income as a Path to Equality, 58 FORDHAM L REV 539 562-63 (1990), but few courts have been willing to impose something like this. For an exception see, Clapp v. Clapp, 653 A.2d. 72 (Vermont, 1994).
} 


\section{HOMOGENEOUS RULES}

child’s school play, helping an elderly parent, organizing a family vacation) simply have no market value. ${ }^{99}$ Compensating for foregone opportunities also makes sense, but the longer the marriage, the more impossible it becomes to determine the contours of what one spouse gave up for the other. Should the law assume that the spouse who decided not to pursue a PhD because she got married would have pursued it otherwise? How should it decide that? Should the woman who dropped off partnership track after her second child be compensated as if she had made partner? What if she was on track to make more than her husband, but the couple decided together that they would rather have the husband be the primary wage-earner? What if the decision was hers alone and he would have preferred that she worked? ${ }^{100}$

Partnership theory is also problematic for alimony theory because when partnerships dissolve the partners do not have any on-going obligation to each other unless it is clearly laid out in the partnership agreement. Alimony involves claims to future earning capacity. When marriage was supposed to be permanent, it made sense to give an ex-spouse a share of the other's future earning capacity. If marriage is no longer meant to be permanent, what justifies giving a spouse any share of the future earning capacity? The reformers of the 1970s seemed happy enough with an answer of "nothing" or "very little.” Judges proved unwilling to impose that answer on women in longer term marriages. Somehow, their status as a wife entitled them to something more than just

\footnotetext{
${ }^{99}$ Katharine K. Baker, The Problem with Unpaid Work, 4 U. OF ST. THOM. L. Rev. 599, 613-614 (2007) (describing unpaid work for which there are no market alternatives).

${ }^{100}$ The question in these cases is not the same as in a tort case in which the jury is asked to assess how much a plaintiff would have earned given the choices she had made before she got hurt. The question for rehabilitative alimony is how much would this ex-spouse have earned if she had made different life choices.
} 


\section{HOMOGENEOUS RULES}

what they needed or what they might use to piece together an alternative life at age 45 or 50.

A consensus of sorts is emerging though. Legislatures are increasingly prohibiting alimony in shorter marriages, while lawyers and judges are promulgating guidelines for longer term marriages. Texas and California prohibit alimony in marriages of less than 10 years and several states set a maximum number of months for alimony. ${ }^{101}$ Meanwhile, the American Academy of Matrimonial Lawyers developed guidelines for alimony after concluding that there were two significant and related problems with spousal support, "lack of consistency resulting in a perception of unfairness” and “inability to accurately predict an outcome in any given case.”102 Supreme Courts in Pennsylvania, Georgia and Nevada have recommended the adoption of spousal support guidelines. ${ }^{103}$ Counties in Arizona, California, New Mexico, Kansas, Michigan, Virginia, Nevada, Oregon and Pennsylvania have all developed formulas or guidelines that provide at least a starting point for an alimony award. ${ }^{104}$ Various judges in Massachusetts, on their own, developed numerical formula, based on their past decisions, that they use as guides for future decisions. ${ }^{105}$

Possibly most influentially, the ALI Principles recommend an alimony formula, which they base on a theory of "spousal compensation," and which like all of the guidelines just discussed, consider two different variables, income of the spouses and

\footnotetext{
${ }^{101}$ J. Thomas Oldham, Changes in the Economic Consequences of Divorce, 1958-2008, 42 FAM. L. Q. 424, 432 (2008).

${ }^{102}$ Report of the American Academy of Matrimonial Lawyers on Considerations When Determining Alimony, Spousal Support or Maintenances Approved by Board of Governors, March 9, 2007.

103 An Update on Florida Alimony Case Law: Are Alimony Guidelines a Part of Our Future?, FLORIDA BAR JOURNAL, November 1, 2003

${ }^{104}$ Mary Kay Kisthardt, Re-thinking Alimony: The AAML's Consideration for Calculating Alimony, Spousal Support or Maintenance, 21 J AMER. ACAD. OF MATRIM. LAWYERS 61, 73-77 (2008).

${ }^{105}$ Scott Stevenson and Justin Kelsey, The Divorce Spousal Support Calculator: An Alimony Formula Resource (Revised Feb. 12, 2010) (describing the different formula used by Massachusetts judges).
} 


\section{HOMOGENEOUS RULES}

duration of the marriage. ${ }^{106}$ If the income differential is significant enough and the marriage lasted long enough, the guidelines provide a set of multipliers for determining alimony. The amount is a function of the income of the parties. The duration is a function of the length of the marriage.

\section{Summary}

Together, these various formulas for child support, property distribution and alimony leave little for the law, or anyone, to contextualize when family forms are altered. For instance, a father of one who is getting divorced after a 15 year marriage in which he was the primary breadwinner will owe some readily discernible amount of child support (20-25\% of his income), half the value of any property that he acquired by his own labor during the marriage and probably some readily discernable amount of temporary alimony if the future income differential between himself and his spouse is substantial. There is no reason for this hypothetical father to go to court because a judge's job would be to apply the same formulae that anyone with an ability to read a statute could apply.

But consider who else need not go to court. The man who never wanted a child, never lived with the child's mother, never functioned as a father, but had a sexual relationship that resulted in pregnancy would owe the exact same amount of child support as the first father (assuming he earned the same amount) in child support. A man who came into a mother's life after a child was born (or maybe even before), lived with and provided for the child, and functioned as a father, would owe nothing if a legal father existed elsewhere. It is the status of fatherhood that matters.

\footnotetext{
${ }^{106}$ Kirsthardt, supra note 104 at 78.
} 


\section{HOMOGENEOUS RULES}

A husband whose wife spent an entire childless marriage in graduate school only to decide she was not sure that she cared about a graduate degree and wanted instead to become a painter, must divide any property he earned during their marriage in the exact same manner as the husband whose wife mothered 3 children, decorated their home, cooked all the meals, tended to his parents, coached 4 sports teams and ran the PTA. It is the status of marriage that determines whether the proceeds of marital labor must be shared equally. Comparably it is the length of the marital status and the earning differential between the spouses, not the particularities of the marriage that determine an alimony obligation. The next section probes those obligations even further.

\section{The Formulas Critiqued}

\section{A. Child Support}

As just described, legal parents of children may owe or receive child support payments. In 2009, $\$ 31.7$ billion was transferred in child support. ${ }^{107}$ The total amount of arrearages for previous years was over $\$ 107$ billion. ${ }^{108}$ Estimates suggest that thirty percent of the United States' adult population probably was or is a payor or payee of child support. ${ }^{109}$ Child support is big business. Yet the underlining methodology used to established those billions of dollars in child support liability is based on highly suspect data, woefully outdated assumptions about family norms, and contested understandings of appropriate duties.

As those who work closely with the guidelines are well aware, the average marginal expenditure figures that form the core of the guideline obligation structure are

\footnotetext{
${ }^{107}$ Figure 6, US Dept of Health and Human Services, Office of Child Support Enforcement FY 2009 Preliminary Report, http//www.acf.hhs.gov/programs/cse/pubs/2010/reports/preliminary_report_fy2009. ${ }^{108}$ Id. at 2.

${ }^{109}$ Ira Mark Ellman and Tara O’Toole Ellman, The Theory of Child Support, 45 HARV. J. ON LEGIS. 107, 121-123 (2008).
} 


\section{HOMOGENEOUS RULES}

deeply flawed. ${ }^{110}$ To highlight just the most obvious flaws, the guidelines use average

data and there is strong reason to believe that because so many individuals have such different ideas about when, why and how one should spend money on children, there is huge variation around the mean. ${ }^{111}$ Attention to context would demand attention to those differences.

The guidelines also rely on marginal data, probably either because (i) economists are used to relying on marginal data or (ii) the guideline drafters want to preference the interest of the non-residential parent. The first explanation for using marginal data is just silly, ${ }^{112}$ but the second is not well justified either. Marginal data tells us how much more a two-adult household may need to spend to maintain the same standard of living once a child arrives, but it tells us nothing about the average cost or expenditures of a one parent household with a child. The marginal expenditure figure ignores both the economies of scale reaped by two adults living together and the joint consumption that inevitably follows when a parent lives with a child. ${ }^{113}$ What it captures is what one parent, who was living with the other parent, would have expected to pay in added costs once a child

\footnotetext{
${ }^{110}$ Professor Ira Ellman has written extensively about the problems with the child support formulas. See Id.; Ellman, supra note 64, Ellman, supra note 94 and Ira Mark Ellman, Inventing Family Law, 32 UC DAVIS L REv 855 (1999).. Professor Grace Blumberg was the reporter who worked most closely with the ALI Principles re-formulation of child support guidelines. Id. Both scholars readily acknowledge the limitations of the marginal expenditure figure.

${ }^{111}$ See Laurie J Bassi and Burt S Barnow, Expenditures on Children and Child Support Guidelines, $12 \mathrm{~J}$ Pol ANAL. AND MANAGEMENT 478, 486 (1993) (suggesting that one needs a spread of 21 percentage points to capture $80 \%$ of the families around the mean).

${ }^{112}$ Ira Ellman suggested that that the use of marginal numbers may simply be the result of economists acting pursuant to the standard economic question, whether the marginal cost of one more widget is less than the economic benefit. But, as Ellman, notes, one parent post-dissolution households are "like a new entr[ies] into the widget business. They are start-ups.” See Ellman, supra note 64 at 187. As such, they need to consider all costs associated with a one parent household, not just the marginal costs associated with a two parent household.

${ }^{113}$ For instance, a child may not produce the need for another car in a 2 adult household with one car, but the existence of a child may necessitate a car in a single parent household. Likewise, the existence of a child may not raise the cost of heating or cooling a 2 bedroom apartment, but the custodial parent who lives with a child in a two bedroom apartment should arguably be entitled to child support payments that help pay for the heat and air conditioning the child needs. The marginal figure ignores those costs.
} 


\section{HOMOGENEOUS RULES}

arrived. As the comments to the ALI Principles state, this "most frequent measure of American child support is better understood as an expression of the interests of the nonresidential parents.”114

The deference to non-residential parents has been explained and partly defended as reflecting the "intuitive” understanding that each individual has the first claim to his own income. ${ }^{115}$ “The higher income parents, whether a residential or nonresidential parent, has an interest in benefiting disproportionately as compared to other family members from the fruits of his or her own labor."116 A nonresidential parent certainly does have that interest, but the extent to which that interest should trump the interests of the child or the residential parent may depend a great deal on context and the interdependencies that have or have not developed.

Finally, the expenditure figures on which the formulas rely are based on the notion that we can generate accurate equivalence scales for determining when two households with a different number of inhabitants experience the same standard of living. Do two household that spend the same amount on adult clothing really share the same standard of living? The equivalence scales presume that they do. ${ }^{117}$ Professor Ira Ellman, who has done more than anyone to highlight the flaws in child support methodology, summarizes the use of equivalence scales as "empirically unverifiable, theoretically questionable, and ... [based on] . . f flawed data.”118 In short, there are

\footnotetext{
114 ALI PRINCIPLES, supra note 67,§3.04, Comment e., p 427.

115 Professor Ellman has explored this principle in at least two works, Ellman and Ellman, supra note 109 at 121-123 (2008) and Ira Mark Ellman, Sanford Braver and Robert MacCoun, Intuitive Lawmaking: The Example of Child Support, 6 J OF EMPIRICAL LEGAL STUDIES 1 (2009).

${ }^{116}$ ALI PRINCIPLES, supra note 67, §3.04, Comment d., p 425

${ }^{117}$ Ellman, supra note 64 at 215

${ }^{118}$ Id. The Equivalence scales assume that one can make reliable assessments on spending patterns by looking at only a selected few kinds of expenditures. Most scales use adult expenditures on clothing to assess standards of living in two adult households. Two households that spend the same amount of money
} 


\section{HOMOGENEOUS RULES}

loads of reasons to question the implicit policy choices upon which the guidelines are based. The ALI Principles try to address some of these problems by introducing a measure that helps ensure that a child's standard of living will not be "grossly inferior to that of either parent."119 But the base measure used by the ALI still relies on average marginal expenditure data and, more fundamentally, takes as its primary interest the idea that a child "is to be economically unharmed by family dissolution."120 But for a family to have dissolved, it had to exist in the first place. What is or was the child's family and why should the law consider it dissolved?

\section{What Family?}

Recall the demographic data above. Forty percent of children in this country are born to unmarried mothers. Less than half of those are born to cohabiting couples (meaning the parents actually share a household) and half of the children born to cohabiting couples see their household split by age 9 . $25 \%$ of children born to married couples see their household split by age 9 . Thus $20 \%$ of children never live in the two parent home upon which the econometric model is based and another $25 \%$ see that home dissolve before age 9. Another substantial percentage of children have their two parent

on adult clothing are thought to have the same standard of living. As Ellman details, see id. at 210-216, the methodology used to generate these results are unverifiable. The notion that one can make such grand conclusions from adult clothing data alone is suspect, and the results are known to underreport income in low income households and underreport expenditures in high income households. In practice, this makes it seem as if low income groups pay a greater percentage of their income on children than they actually do and as if high income groups spend less on their children then they actually do.

119 See ALI PRINCIPLES, supra note 67, § 3.05(3)(b). The current guidelines, whether "income shares" or "POOI," do an adequate job of ensuring comparable standards of living in both the custodial and noncustodial household if the custodial and non-custodial parent have comparable amounts of income. Unfortunately, this is very often not the case so stark standard of living disparities between custodial and noncustodial households are common. See Thomas Oldman, Appropriate Child Support Award when the Noncustodial Parent Earns Less than the Custodial Parent, 31 Hou. L. REV. 585, 598 (1994-1995).

${ }^{120}$ ALI PRINCIPLES , supra note 67, §3.04 Comment c., p. 424. 


\section{HOMOGENEOUS RULES}

household dissolve after age 9. Yet that hypothetical two parent household serves as the basis of all child support obligation.

Many unmarried women have children while still living with their own parent(s). Part of the reason these women do not live on their own is because neither they nor the men with whom they have children can afford a home on their own. ${ }^{121}$ The child support model assumes that home exists. Why should the model be based on an ideal that is beyond the reach and/or not desirable for so many parents?

As indicated earlier, most of the children who do not spend their childhoods living with both of their parents live with and/or are cared for by other adults. One-third of all children spend some time before age 18 in step-families. ${ }^{122}$ Step-parents often bring new children into the household or have obligations to children outside the household.

Should either the composition of the new household or the existence of another one affect the obligation of child support payors? Who should the payor be? Why is the first often hypothetical - household the only one to determine child support obligation?

Attention to context would require incorporating different living situations into obligation determinations. $^{123}$

\section{Multiple Parents ?}

\footnotetext{
${ }^{121}$ See Judith Stacey, In the Name of the Family: Rethinking Family Values in the Postmodern Age 30, 4045 (1996) (discussing inability of low income and working class men to support a household); Kathryn Edin \& Laura Lein, Making Ends Meet: How Single Mothers Survive Welfare and Low-Wage Work, at 5864 (1997).

122 Larry L Bumpass et al., The Changing Character of Stepfamilies: Implications of Cohabitation and Nonmarital Childbearing, 32 DEMOGRAPHY 425 (1995) (this figure includes the children of split cohabiting couples as well as the children of divorced couples, and counts as step-parents any partner of the child's primary parent who lives in the household).

${ }^{123}$ Some courts do take pre-existing obligations into account when setting child support amounts, but the trend is away from doing so. Leslie Harris, The ALI Child Support Principles: Incremental Changes to Improve the Lot of Children and Residential Parents, 8 DUKE J. GENDER L. \& POL'Y 245, 253 (Spring/Summer 2001).
} 


\section{HOMOGENEOUS RULES}

Then there are all the other varieties of parents. Despite what some believe is the decline of the extended family, grandparents often play a prominent role in the lives of single parents. ${ }^{124}$ In many communities of color, relatives and close friends play a critical role in caring for children. ${ }^{125}$ Numerous commentators call for members of these “caretaking networks” to be treated as family. ${ }^{126}$ The ALI Principles suggest that custodial time be awarded to “de facto parents," adults who have spent a significant amount of unpaid time taking care of a child.

Should these alternative caretakers be assigned legal obligations as well legal rights? Far fewer commentators address this. ${ }^{127}$ As I have argued elsewhere, the law could logically impose obligation on anyone who enjoyed custodial rights, ${ }^{128}$ but it does not. In a thoughtful review of some of the literature, Professor Susan Appleton has commented that obligation can be dispersed just as custodial time is because both time and money are easily divisible. ${ }^{129}$ Appleton does not address the theoretical vacuum at the core of any divisible award, though. If the obligation is going to be split between 3 (or 4, or more) “parents,” why and how should it be based on an econometric formula based entirely on a two-parent household?

\footnotetext{
${ }^{124}$ ANDREW J. CHERLin \& FrANK F FurStENBURg JR., THE NEW AMERICAN GRANDPARENT 163-64 (1986).

${ }^{125}$ Natalia Sarkisian \& Naomi Gerstel, Kin Support Among Blacks and Whites: Race and Family Organization, 69 Am Soc ReV 812 (2004).

${ }^{126}$ Melissa Murray uses the term caretaking networks, see, Murray, supra note 28. Other scholars clearly support the idea. Kessler, supra, note 32; Dorothy Roberts, The Genetic Tie, 62 U CHI L Rev 209 (1995).

${ }^{127}$ Both Susan Appleton, Parents by the Numbers, 37 HofsTRA L ReV 11, $34-37$ (2008) and Melanie Jacobs, More Parents, More Money, Reflections on the Financial Implications of Multiple Parenthood, 16 CARDOZO J L \& GENDER 217 (2010), have at least tried to address this question, but many other scholars seem to leave it for another day.

${ }^{128}$ Katharine K. Baker. Asymmetric Parenthood in RECONCEIVING THE FAMILY, supra note 89 at 121, 129 (arguing that anyone who receives custodial time with the child by virtue of their relationship with the child could easily be held liable for some support of the child by virtue of their relationship with the child. The ALI envisions allotting some people custodial time without making them liable for any child support.)

${ }^{129}$ Appleton, supra note 127.
} 


\section{HOMOGENEOUS RULES}

The very few courts that have awarded parental status to more than two adults have ignored this problem. ${ }^{130}$ A Louisiana trial court that held two men (and one woman) responsible as parents added the income of all three parents together and then plugged that sum into the existing guidelines to determine an appropriate amount of support. ${ }^{131}$ It then divided responsibility for that amount of support between the genetic father and the husband of the mother, who had acted as a parent to the child. The appellate court approved of this methodology because it was "in keeping with the spirit of the guidelines,"132 but using the guidelines in this context resulted in a number that was completely arbitrary - rooted in no theory whatsoever. There is no equivalence scale for a three parent household. The three parents were never a family that dissolved. The child never experienced a household in which all the resources were shared and it is highly unlikely that sharing resources as a 3 adult household was ever an ideal for the parties.

The key principle of the formula-drafters, that the non-custodial parent should pay no more than he would pay if the household were in tact, loses all coherence if there are three parents. ${ }^{133}$ The numbers the court used were derived from data involving a 2 adult households. Three adult households could be very different - but we are not likely to know because tabulating equivalence scales for 3 adult households would require

\footnotetext{
${ }^{130}$ See Jacob v. Schultz-Jacob, 923 A.2d 473 (2007) (finding three adults responsible for child support, the biological mother, her ex-partner who had adopted the children and the male sperm donor who had played an active role in the children's life and been awarded custodial time and remanding for the trial court to determine the amounts of child support. The sperm donor died while the case was pending so no court had to determine actual obligations. See PitTSBuRgh Post-GazetTe, Court Orders Sperm Donor to Pay Support; Death of Father Complicates Case, May 11, 2008, Sooner Edition); Smith v. Cole, 553 So.2d 847 (La. 1989) (finding both a marital father and a biological father responsible for child support, but not providing details of what each should pay or why).

${ }^{131}$ Wilson v. Wilson, 855 So2d 913 (La. App. 2 Cir 9/24/03).

${ }^{132}$ Id. at 916.

${ }^{133}$ That is, unless the three parents agreed amongst themselves to be joint parents and all share in the obligation. But even then, the formulas would have an equivalence scale problem.
} 


\section{HOMOGENEOUS RULES}

finding enough 3 adult households both with and without children to make the scales meaningful. If the law is to embrace the idea of three or more parents it needs to either (i) develop new formulae calculating the marginal expenditure amounts for multiple adults living in the same households as parents of the same children - though that is a model that is particularly likely to be counterfactual and deeply contested as an ideal or (ii) accept the legitimacy of a system that uses arbitrary percentages to establish child support obligation.

\section{Intended Families?}

Also curiously absent from the child support formulae is any consideration of an adult's degree of commitment to parenthood. All child support statutes piggyback onto parentage acts to determine parental status. The support obligation is based on that status and nothing else. Thus, a man who never intended to be or acted as a father, but is found responsible in a paternity action based on his genetic connection to the child is responsible for the exact same amount as the man who committed to both the decision to conceive and the child once born. ${ }^{134}$

Marriage is also usually irrelevant to parental obligation, though one could easily argue that that a pre-existing commitment to the ideal family unit on which the child

\footnotetext{
${ }^{134}$ Parentage Acts are not as clear-cut as they first appear. They almost always give a mother the right to establish paternity in a man who is genetically related to the child, as long as the child was not born through some form of artificial insemination. See Baker, supra note 29 at 10-12 (explaining how parental status based on genetic connection can be waived in case of artificial reproduction). At the same time, parentage acts establish presumptions of paternity based on marriage and living patterns. (The husband of a mother is presumed to be the father as is a man who holds himself out as a father of a child.) It is not uncommon for these presumptions to clash with each other or with biological evidence. When there is just one potential father involved, genetic evidence usually establishes paternal status. When there are more than two potential fathers involved, things get much more complicated. Some judges use best interest of the child tests to determine whether the genetic evidence should trump. Other judges use best interest of the child determinations to exclude genetic evidence. See id. 12-14 (discussing law and cases). For a more general discussion of the inconsistencies in paternity doctrine, see id at $1-38$. The incoherence of paternal status determinations, particularly for fathers, just makes the child support guideline's reliance on those determinations more problematic.
} 


\section{HOMOGENEOUS RULES}

support guidelines are based should be relevant if one is to be found accountable under those guidelines. If the law took the marital commitment seriously, it might make distinctions between the person who was willing to make a commitment to a family and the person who was not. The de-stigmatization and constitutional protection of nonmarital sex makes it clear that a man who engages in consensual non-marital sex has done nothing wrong. The decision to have the child is not his at all. ${ }^{135}$ Why is it inappropriate to hold a man who never committed to anyone or desired any child to a lesser obligation than a man who did so commit? Contraception does fail. Men are lied to. If the law should pay more attention to context, as the vast majority of the scholarship in favor of more expansive parenthood argues, shouldn't the law also make distinctions between those men who want children and those that do not?

In 1972 the Supreme Court rejected the idea that treating illegitimate children less favorably than legitimate children discouraged non-marital sex. ${ }^{136}$ Constitutional doctrine now forbids state from sanctioning most non-marital sex, ${ }^{137}$ but a marital/nonmarital distinction for child support need not be rooted in punishing extra-marital sex or illegitimate children. It can be rooted in the notion that marriage is a proxy for commitment to a child who is born to the family created by marriage. After all, married men commit $50 \%$ of their earned wealth to their spouses. Why do they commit less to their children?

\footnotetext{
135 The man has no say in whether the pregnancy is terminated. See Baker, supra note 29 at 18 (2004) (arguing that the constitutionally protected reproductive decision-making accorded to the mother makes her the proximate cause of the child's existence).

136 Trimble v. Gordon, 430 US 762, 769 (1977). A crucial advantage, from the state's perspective, of holding non-marital fathers liable for child support is that it helps keep dependencies private, see Katharine K. Baker, Bionomativity and the Construction of Parenthood, 42 GA. L. REV. 649, 671-673 (2008), but a policy decision in favor of holding non-marital fathers responsible for child support is not the same as a policy decision in favor of holding non-marital fathers responsible for the same amount as marital fathers. ${ }^{137}$ Lawrence v. Texas, 539 U.S. 558 (2003) (finding a right to engage in homosexual sodomy).
} 


\section{HOMOGENEOUS RULES}

\section{Alternative?}

The modern reality of parenting seems to bear strikingly little resemblance to the ideal on which the child support obligation formulae are based. Many parents never live in the household on which the model is based. Some parents do not want to. Others experience the two parent "norm" only temporarily and most who never live it or leave it eventually live in a different kind of family structure. Those who embrace the ideal and the commitments it is thought to embody are treated just as everyone else if for obligation purposes. And even if we accept the legitimacy of rooting obligation in a (very) hypothetical ideal, we must grapple with the child support formulae's use of inaccurate data, unverifiable conclusions and contested notions of entitlement.

One can fairly easily imagine an effective, if completely arbitrary, alternative regime. Every non-custodial parent could be required to pay 15\% of his income toward his children (with perhaps decreasing percentages per child). Parents who clearly intended to parent might pay more, say $25 \%$. If there were some parents who had substantially fewer parental rights, they could be ascribed a different, lesser percentage, say $10 \%$. These percentages are not derived from anything. I made them up. But if put into practice, they would likely not seem any more or less consistent with what parental obligation should be than the current numbers. In fact, they might be perceived as more fair because they incorporated more context. This alternative system could work almost as efficiently as the current one ${ }^{138}$ and would not be subject to the same methodological critique because there would be no methodology from which the numbers were derived.

\footnotetext{
${ }^{138}$ It would not be quite as efficient because courts would have to determine who had "substantially fewer" parental rights, but that analysis would probably be done as part of the parentage and parental rights adjudications that are currently being conducted without any consideration of whether the allocation of rights should affect the allocation of responsibilities. See Katharine K. Baker, Marriage and Parenthood as Rights and Status 71 Оніо Sт. L. J. 127, 180-81 (2010)
} 


\section{HOMOGENEOUS RULES}

The state would simply impose them. Parenthood would entail a 15\% obligation because that is what the law said parenthood was, but that is hardly different than what the law does now.

\section{B. Property Division}

Domestic Relations cases constitute slightly less than one quarter of all civil law cases filed in state courts. ${ }^{139}$ Of those domestic relations cases, almost 30\% involve divorce. ${ }^{140}$ Of those divorce cases, virtually all require some distribution of assets and debts. ${ }^{141}$ The vast majority of that distribution is negotiated between the parties without judicial evaluation. Ninety percent of divorce cases settle, ${ }^{142}$ and unlike most civil litigants, divorcing parties usually negotiate a settlement without an interlocutory judicial decision giving them some indication of how the trial might go. ${ }^{143}$ The established background legal rules are thus critically important in setting the parameters within in which the parties bargain over the billions of dollars in property that are divided. ${ }^{144}$

As Part II suggested, although not as rigid as the child support formulas, most states have now settled on a clear, rule-based property distribution system. It is far simpler than the child support formulas: each party receives half of all marital property

\footnotetext{
${ }^{139}$ Natl. Center for State Courts, Examining the Work of State Courts, An Analysis of 2007 State Court Caseloads (2009) 13 (excluding criminal, traffic and juvenile cases, domestic relations cases constitute $23.9 \%$ of the remaining state cases).

${ }^{140} \mathrm{Id}$.

${ }^{141}$ Not all parties have assets to be divided, but most couples that do not have assets, have marital debts to be distributed.

${ }^{142}$ D. Abrams, N. CAhn, C. Ross And D. Meyer, Contemporary Family LaW 921 ("Mirroring the overwhelming percentage of civil disputants who settle out of court, more than $90 \%$ of divorcing spouses and other domestic relations disputant resolve financial and child-related matters alike by negotiation before requesting the court to enter the final decree in accordance with their agreement.)

${ }^{143} \mathrm{Id}$.

${ }^{144}$ See Robert Mnookin and Lewis Kornhauser, Bargaining in the Shadow of the Law, 88 YaLE L J 950, 950-951 (1979). ("We see the primary function of contemporary divorce law not as imposing order from above, but rather as providing a framework within which divorcing couples can themselves determine their post-dissolution rights and responsibilities.”)
} 


\section{HOMOGENEOUS RULES}

or at least judges start from that presumption. Marital property includes all property produced by either spouse’s labors during the marriage. The ALI Principles strongly endorse an equal division of marital property. ${ }^{145}$

There is something intuitively appealing about a 50/50 background rule. It suggests a paradigm of marriage as an equal partnership with equal participation from the parties. It relies on what Professor Susan Prager referred to as “sharing principles," the idea that married parties presume, or should be encouraged to presume, that they share what they have with their spouse. ${ }^{146}$ As for how much should be shared, the comments to the ALI Guidelines suggest, "in the absence of reasons to the contrary, one adheres to the default meaning of fair, which is equal.”147 The history, theory and contemporary context of property distribution suggest that there are plenty of reasons to question the notion that fair means equal though.

\section{Rooted in History?}

The genesis of the 50/50 presumption in the common law states is usually traced to the original 8 community property states. ${ }^{148}$ A leading Family Law text writes "[e]quitable distribution of property in the United States is an outgrowth of the systems of community property introduced into the Western Hemisphere by Spanish and French settlers." ${ }^{149}$ That text goes on to quote a major treatise on community property:

Equality is the cardinal precept of the community property system. At the foundation of this system is the principle that all wealth acquired by the joint efforts of the husband and wife shall be common property .... [T] he marriage is

\footnotetext{
145 ALI PRINCIPLES, supra note 67, § 4.04, Comment c., p. 665.

146 Susan Prager, Sharing Principles and the Future of Marital Property Law, 25 UCLA L Rev 1 (1977).

${ }^{147}$ ALI PRINCIPLES, supra note 67, §4.10, Comment b, p. 752. In defending the same provision, Ira Ellman writes, "any group of schoolchildren dividing a bag of candy [knows] the default meaning of fair is “equal.” See Ellman, Inventing Family Law, supra note 110 at 884.

148 See supra note 70 for a list of the states.

149 John DE WitTt GREgory, PETER SWisher AND SHERYL WOLF, UNDERSTANDiNG FAMILY LAW at 388 (2005).
} 


\section{HOMOGENEOUS RULES}

a community of which each spouse is a member, equally contributing by his or her industry to its prosperity, and possessing an equal right to succeed to the property after its dissolution. ${ }^{150}$

That language goes down quite smoothly now, probably even more smoothly than when it was written, in 1971, but it only faintly reflects the history of community property. Community property regimes did not traditionally construct marriage as a community of equals. Women were nominal owners of half of the property in community property states, but during the marriage, community property states gave the husband the sole power to manage (or mismanage) marital assets. ${ }^{151}$ It was not until changing social norms and constitutional gender equality cases began to force legislative change in the mid-1970s that women were given the authority to exercise control over community property while the marriage was intact. ${ }^{152}$

Just as important, as Charles Donahue chronicled, community property regimes were not founded on notions of equality in or after marriage. They were largely an outgrowth of feudal systems in continental Europe that were concerned with maintaining family wealth by restricting individuals' ability to alienate family lands. ${ }^{153}$ The parallel development of different systems in England and on the Continent can be explained by the relative strength of monarchical power and a more conscious desire to simplify ownership so as to facilitate development in England, versus the decentralization of power in large feudal families and a strong desire to keep power in those families by

\footnotetext{
${ }^{150}$ W DeFuniaK \& M VAughn, Principles of COMMUnity Property, at 2-3 (1971).

${ }^{151}$ Harris, Teitelbaum, Carbone, , supra note 56 at 50-51. The Supreme Court struck down the community property practice of vesting authority to manage marital funds in the husband in Kirchberg $v$. Feenstra, 450 US 455 (1981).

${ }^{152} \mathrm{Id}$. at 51.

153 Donahue, supra note 73.
} 


\section{HOMOGENEOUS RULES}

restricting alienation in France. ${ }^{154}$ If a woman in Continental Europe divorced or if her husband died (far more likely), her family retained half of the marital estate. In England, a much larger share of the estate went to the husband's heirs. ${ }^{155}$ As Donahue wrote, “[i]t is hard to escape the general conclusion that what looks at first blush like a system more favorable to the woman was in fact a system more favorable to the woman's family." It has only been in the last 40 years that community property rules have come to be viewed as partnership rules, reflecting the idea that spouses are marital equals, fully entitled to equal shares of marital property.

\section{Partnership?}

It is too simplistic, though, to state that either community property regimes or the current equitable distribution rules reflect background partnership principles.

Partnerships can only be treated as such legally if they involve "two or more persons [carrying] on as co-owners a business for profit."157 What business are two persons carrying on in a marriage? It is not, as it possibly once was, to have children. Empirical work confirms that most people think the reason to marry is for "mutual happiness and fulfillment," much more than for "bearing or raising children” and certainly more than to make money. ${ }^{158}$

\footnotetext{
${ }^{154}$ Id. at 78-84 (Donahue goes on to argue that the fullest explanation of the parallel development of different systems also requires taking account of the French notion of family community, which had always involved more sharing of wealth among family members than was common in England. Id. at 85-87.)

${ }^{155}$ A widow still would have been entitled to her dower, roughly $30 \%$ of his property, at his death.

${ }^{156}$ Donahue, supra note 73 at 80.

${ }^{157}$ UNIFORM PARTNERSHIP ACT §6.

158 "[B]y a margin of three-to-one, Americans say that the main purpose of marriage is the "mutual happiness and fulfillment' of adults rather than the 'bearing and raising of children.'” See Marriage and Parenthood, supra note 5 at 2.
} 


\section{HOMOGENEOUS RULES}

Viewing marriage as an economic partnership also assumes a degree of financial enmeshment that seems at odds with many modern descriptions of marriage. Consider this definition of marriage, suggested by a leading legal scholar thirty-five years ago:

Contemporary marriage cannot be legally defined any more precisely than as some sort of relationship between two individuals of definite duration, involving some kind of sexual conduct ... that may be formed by the consent of both parties and dissolved at the will of either. ${ }^{159}$

The law of business partnership assumes that the joint venture has a purpose and that purpose is economic. Modern marriage seems to have no purpose except personal fulfillment, and it is not clear why that need involve any economic commitment. In one of the leading cases embodying the changing sexual, social and constitutional norms of the 1970s, the Supreme Court held that "the marital couple is not an independent entity . . . but an association of two individuals, each with a separate intellectual and emotional make-up.”160 Why did the law contemporaneously impose a rule that treats marital partners as one economic entity?

The vast majority of business partnerships involving any venture with profits to be divided also have partnership agreements that explicitly define how profits are to be distributed. It is disingenuous to suggest that because the default rule for partnerships is equal division, equal division rules for marital property rely on partnership norms. The default rule for partnerships is routinely contracted around, while the default rule for marriages almost never is. ${ }^{161}$

\footnotetext{
${ }^{159}$ Homer Clark, The New Marriage, 12 WiLlametTe L. J. 441, 444 (1976).

${ }^{160}$ Eisenstadt v. Baird, 405 US 438, 453 (1972).

${ }^{161}$ Prenuptial agreements are more common than they once were, but the vast majority of marriages do not include them. Gary Belsky, Living by the Rules, MONEY, May 1996 at 100, 102 (suggesting that only 5\% of marrying couples sign prenups). Moreover, as suggested infra text accompanying notes 172-175, the fact that prenuptial agreements routinely contract around the 50/50 rule suggests that "fair" does not necessarily mean "equal."
} 


\section{HOMOGENEOUS RULES}

\section{Sharing Principles?}

Nor can "sharing principles” adequately explain the current property distribution rules. For sure, Professor Prager is correct that though they are not required to, many spouses approach their marriage as a sharing enterprise. Couples share, among other things, decision-making, income, time, and property. But not all couples share the same amounts of these things. More important, the extent to which they are willing to share while married can vary significantly from the amount that they think they should have to share at dissolution. While married, while in sharing mode, a spouse is most likely sharing her inherited property with her spouse. At divorce, she probably does not want to share that inherited property anymore and the law does not make her. None of the community property states in this country consider inherited property to be marital property and the vast majority of common law states exclude it also. Those "hotchpotch" states $^{162}$ that do consider all property, from wherever derived, subject to dissolution at divorce, routinely stray from the 50/50 rule in order to award inherited property to the party that inherited it. ${ }^{163}$

Thus, it is not the idea of sharing that explains what should count as marital property. The current rule, that what must be split is all property produced by marital labor has been justified because “marriage involves the commitment of both spouse's labors." ${ }^{\prime 164}$ But that is a simply a normative declaration of what marriage should be. It is potentially both under and over-inclusive. It does not include all property earned during the marriage, because many states treat appreciation of non-marital property as non-

\footnotetext{
162 See, supra, note 78.

163 OLDHAM, supra note 72, §3.03[3].

${ }^{164}$ ALI PRINCIPLES, supra note 67,§4.04, Comment c, p. 665.
} 


\section{HOMOGENEOUS RULES}

marital property. ${ }^{165}$ It does not include all assets acquired during the marriage because, particularly if people are married in their 20s and 30s, the largest asset acquired is likely to be human capital, which courts, for the most part, have resisted dividing as marital property. $^{166}$

It also may include more property than many people think appropriate. What happened to the "intuitive" idea, so prevalent in child support, that each individual has the first claim to his own income? ${ }^{167}$ Why, if a payor is not expected to share anywhere near half his income with his child or children while they are minors, ${ }^{168}$ should he be expected to pay half his income to his wife while the marriage is active?

\section{d. Contribution?}

One answer to this is that spouses, unlike children, have earned their 50\% share. Theorists concerned about women’s welfare tried for years to argue that women’s nonmonetary contributions to a marriage entitled them to an equal share of the joint marital labor. But the market value of women's unpaid domestic labor often comes nowhere near half of the man's economic contribution. More problematic still is the incommensurability of much of women's marital investment. ${ }^{169}$ Women tend to invest

\footnotetext{
${ }^{165}$ David Hofstein, Scott Finger, Ellen Weiner, Update to Equitable Distribution in Large Marital Estate Cases, 21 J. AM. ACAD. MATRIMONiAL LAW 439, 447 (2008).

${ }^{166}$ Carbone, supra note 88 at 62.

167 This is the Earner's Priority Principle, referred to above. See supra note 115.

${ }^{168}$ A parent with many children may have to pay close to $50 \%$ of his income, but, for instance under a typical POI statute, a payor does not reach 50\% until he has 6 children, and then the amount is capped at 50\%. See 750 ILCS 5/505.

${ }^{169}$ See supra notes 99-100 and text accompanying (market value of women's domestic services is often quite low and many households contributions simply have no market value).
} 


\section{HOMOGENEOUS RULES}

more in relationship-specific labor than men do. ${ }^{170}$ Relationship-specific work rarely has any market value or even value that might transfer to a future relationship. ${ }^{171}$

Recognizing that women tend to disproportionately contribute this noncommodifiable labor is undoubtedly important in devising any marital property distribution scheme, but recognizing the commensurability problem does not tell us how women's labor should be valued. How does the law get from incommensurability to 50/50? Apparently by fiat. The ALI simply asserts: "the incommensurability of the spouse’s nonfinancial contributions frustrates any effort to attach monetary value to them. Faced with this measurement difficulty, it may be sensible for the law to presume irrebutably that the spouse's contributed equally to their entire relationship.” It may be sensible. But it is also just a definition of marriage, masquerading as a property distribution theory. ${ }^{172}$

When negotiated by the parties themselves, in prenuptial agreements, distributions that stray from the 50/50 rule are not considered unfair because they stray from the 50/50 rule. People enter into prenuptial agreements because they want to avoid

\footnotetext{
${ }^{170}$ Paula ENGLAND AND GEORge FARKAs, Household, EMPLOYMENT AND GENDER, at 44-45, 55-56 (1986). same as marital couples for property distribution purposes. See id, § 6.01 et seq.. This treatment suggests that the ALI would define not only marriage but all cohabitating relationship by the ideological norm of equal sharing. To my knowledge, no court has adopted this norm in the non-marital context and the ALI proposal has been soundly criticized for both undermining marriage, see Lynn Wardle, Maknig Marriage Matter Less: The ALI Domestic Partnership Principles are One Step in the Right Direction, 2001 BYU L REV 1189 (underscoring the importance of treating marriage as a distinct status) and not providing cohabiting couples sufficient freedom to not be married, see Elizabeth Scott, Domestic Partnerships, Implied Contracts and Law Reform, in RECONCEIVING THE FAMILY, supra note 89, 331, 332 (describing the ALI proposal for non-marital couples as "coercive and paternalistic"); Marsha Garrison, Marriage Matters: What's Wrong with the ALI’s Domestic Partnerhship Proposal, id, 305, 306 (arguing that adoption of the ALI rule would "diminish personal autonomy.")
} 


\section{HOMOGENEOUS RULES}

the background property distribution and alimony rules. ${ }^{173}$ Courts in states that require a substantive assessment of whether prenuptial agreements are fair, routinely find that they are, even though they provide for far less than $50 \%$ of the property produced by marital labor. ${ }^{174}$ The growing legal acceptance of prenuptial agreements belies the idea that “fair” necessarily means “equal.”175

\section{Alternatives?}

In short, the 50/50 partnership view of marriage is not well grounded in history. The definition of what counts as marital property is arbitrary. The idea of equal sharing is inconsistent with other principles of family law obligation, like the earner's priority principle, and with accepted notions of entitlement upon dissolution, like the contribution principle. $^{176}$ The defense of the 50/50 partnership view of marriage is a normative one. This is what the law wants marriage to be.

\footnotetext{
${ }^{173}$ For the most part, parties are not free to negotiate potential child support in a prenuptial agreement because the state, pursuant to its Parens Patraie authority, retains the power to determine appropriate child support amounts.

${ }^{174}$ Developments in the Law: Marriage as Contract and Marriage as Partnership: The Future of Antenuptial Agreement Law, 116 HARV. L. REV. 2075, 2081 (May, 2003).

${ }^{175}$ See supra note 147 (for the idea that "fair" means "equal”). See also, Judith Younger, Lovers' Contracts in the Courts: Forsaking the Minimum Decencies, 13 WM. \& MARY J. WOMEN \& L. 349 (2007) (passim) (describing growing tendency of courts to uphold prenuptial agreements in which a spouse got substantially less than one half the property). There is some tension between the very strong ideological underpinnings of the 50/50 rule and the growing acceptance of prenuptial agreements. If the 50/50 divide rule cannot necessarily be justified as anything other than an assertion of what marriage is, the argument for enforcing prenuptial agreements that contract out of that 50/50 divide diminish in strength. If marriage "involves the commitment of both spouse's labors," see supra note , and if a 50/50 divide of the proceeds of that labor is what the law wants marriage to be, why let married people contract around it? Why not tell them they cannot get married instead? The Committee considering modifications to the Uniform Premarital Agreement Act apparently recognizes these tensions. Thomas Oldham, With All My worldly Good I thee Endow or Maybe Not: A Reevaluation of the Uniform Permarital Agreement Act After Three Decades (University of Houston Public Law and Legal Theory Series 2011-A-1) (discussing proposals to impose more restrictions on prenuptial agreements).

${ }^{176}$ In the case of a business insolvency, for instance, creditors divide the proceeds of property in proportion to their respective contributions. See Black's Law Dictionary, "Contribution."
} 


\section{HOMOGENEOUS RULES}

For what it is worth, I agree with the law. I think the 50/50 rule is a good one because it reflects a marital ideal - unity - that I endorse. ${ }^{177}$ The history of marital unity is problematic though. Unity has been used to justify, among other things, married women's inability to own property and their powerlessness in the face of domestic violence. ${ }^{178}$ Many courts and feminists criticize the idea of unity, ${ }^{179}$ though scholars who are protective of notions of family autonomy, are probably more comfortable with it. $^{180}$ My point is simply that marital unity as an ideal is controversial. Why has unity been adopted so easily in the economic context? It does not reflect what are considered to be contemporary views about the roles of individuals within marriage. ${ }^{181}$

Just as we did for child support, we can imagine a different percentage for property distribution and it could be justified as easily on normative grounds. For instance, why not pay more attention to contemporary norms and say that when marital earnings are disproportionate - perhaps when one spouse makes more than three times what the other spouse makes - then the lesser earning spouse should get no more than one third of the marital earnings. The average - remember the child support guidelines

\footnotetext{
177 Carolyn Frantz and Hanoch Dagan have suggested that the 50/50 distribution represents an ideal of marriage as an "egalitarian legal community." Carolyn Frantz and Hanoch Dagan, Properties of Marriage, 104 COLUM L REV 75, 77 (2004). Whatever ideal one thinks the 50/50 rule represents, the property distribution scheme institutes a particular normative view of marriage.

178 The notion of marital unity often traced to Blackstone, who wrote, "by marriage, the husband and wife are one person in law . . . the legal existence of the woman . . . is incorporated or consolidated into that of the husband.” BLACKSTONE, supra note 42 at 442.

179 See CATHARINE MACKinnON, TOWARD A FEMINIST THEORY OF THE STATE 193-194 (1989); Elizabeth Schneider, The Violence of Privacy, 23 CONN.L. REV 973 (1991). Others have noted, thought that the notion of the family as a unit " is seemingly central to the emphasis on "family privacy" and "family autonomy” that characterizes much discussion of the relationship between state and family.” HARRIS, TEITELBAUM, CARBONE, supra note 57at 33

180 For scholars supportive of some idea of unity, see MiLton REgAN, JR. Alone TogEther, LAW AND The Meanings of Marriage (1999) (passim); Anne Dailey, Constitutional Privacy and the Just Family, 67 TUL L REV 955, 1020-21 (1993) ("while the closed doors of the home have shielded abuse, isolation and exploitation, they have at the same time nurtured love and commitment”); Bruce C. Hafen, The Family as an Entity, 22 UC DAVIS L REV 865, 912 (1989) (passim).

${ }^{181}$ See Eisenstadt, supra note 160 ("the marital couple is not an independent entity").
} 


\section{HOMOGENEOUS RULES}

use averages - wife in this country contributes less than a third to married household finances. ${ }^{182}$ That which she receives in excess of her direct contribution could compensate her for her family-specific investment. A one-third distribution rule would even be rooted in history. It was the dower share that wives in common law jurisdictions used to receive as widows and what some early common law jurisdictions used as a presumption for alimony when divorcing wives had no property titled in their name. ${ }^{183}$ Today it would need to go to men or women, but could always go to the lesser earning spouse. ${ }^{184}$

Or, we might adopt a completely different blanket property distribution rule. We could do away with the concept of marital property. In a world of gender equality, it is not so clear what is wrong with the old title based system. Each spouse in a marriage should be careful to title a certain amount of property in his or her own name, or at least jointly. Anything that is held jointly could be distributed evenly. This system would have the added advantage of eliminating entirely the marital property determination stage and it would help put married people and cohabitants on equal footing, which many people might see as a positive, appropriate move for the law to make.

Some people probably believe that, in practice, the law currently reflects a titlebased system because so many marital obligations are resolved through private agreement. Indeed, antenuptial and postnuptial agreements are enforced in most states. The vast majority of litigants negotiate settlements at divorce without contesting anything

\footnotetext{
182 See New Economics, supra note 15 at 16. College-educated wives contribute the most to household income (35\%). Wives with some college contribute 31\% to household income. High school graduate wives contribute $27 \%$ and wives with less than a high school education contribute $20 \%$ to household income. 183 See supra note 88.

${ }^{184}$ This system would be particularly unfortunate for a primary wage earner who is also a primary caretaker, but anyone in that situation is not served well by the current rules either.
} 


\section{HOMOGENEOUS RULES}

in court. Many states also adjudicate cohabitation contracts involving shared property. In all of these cases, though, the background family law rules matter tremendously.

The 50/50 rule creates a status quo bias for all property distribution agreements. ${ }^{185}$ It also sets the unconscionability threshold pursuant to which ante and postnpuptial agreements are evaluated. ${ }^{186}$ Fair does not necessarily mean equal, but the law starts from that presumption.

The background marital property distribution rules are just as important for cases involving non-marital agreements. Plaintiffs in these cases assert contract claims that only make sense in a legal culture that incorporates our extant family law norms and rules. If the idea of marital property were not firmly entrenched, why would a court every imply a contract involving a promise of "one-half equity interest in all real estate acquired” in exchange for services as a "chauffeur, bodyguard, social and business secretary, partner and counselor."187 If there were not background norms validating the

${ }^{185}$ See Russell Korobkin, The Status Quo Bias and Contract Default Rules, 83 CORNELL L. REV 608 (exploring how default rules establish a status quo, which, like most status quos, make alternatives seem more cumbersome). See also Carolyn Frantz, Should the Rules of Marital Property Be Normative, 2004 U CHI L. F 265, 270 ("Even given the availability of private order, the legal rules surrounding issues of marital property tend to stick. That is, whether or not spouses would actually choose these rules in a situation of perfect choice, they end up with them.”) .

${ }^{186}$ See ELLMAN, KURTZ, supra note 56 at 737-38. There is evidence that some courts are becoming increasingly skeptical of the notion of unconscionability and increasingly willing to enforce an agreement whatever its terms. See Younger, supra note 175 (passim) (describing cases in which dependent spouses received considerably less than $50 \%$ of marital assets). Mostly, though, what the cases regarding unconscionability show is that there is significant disagreement about what that term might mean. That is, judges routinely disagree about whether a particular antenuptial agreement is fair enough. Professor Younger's article documents various state supreme courts disagreeing with themselves, id. at 364-378 and even more cases in which trial, appellate and highest courts all disagree with each other, id (passim). One point emerges clearly: there is wild divergence on what different judges are willing to label unfair. That divergence and the extensive litigation costs it engenders mean that the costs of enforcing antenuptial agreements may well not be worth the benefits of drafting them. As long as that continues to be the case, private contracting is not likely to supplant state-imposed rules of obligation. See also Oldham, supra note 175 (discussing proposals to make antenuptial agreements harder to enforce and more "fair.")

${ }^{187}$ Whorton v. Dillingham, 248 Cal. Rptr. 405, 202 Cal App 3d 447 (1988) (the plaintiff in this case alleged both an express, oral contract and an implied contract, but the court was willing to entertain both claims and the existence of the express, oral contract is highly suspect); See also, Marvin v. Marvin, 557 P2d 106 (1976) (alleged contract to "share equally any and all property accumulated as a result of their efforts 


\section{HOMOGENEOUS RULES}

idea of alimony, why would a dependent person's reliance on a paramour's promise to

“support her for life” be remotely reasonable? ${ }^{188}$

Plaintiffs in these non-marital cases do not rely on unjust enrichment or quantum

meruit claims. Their awards would be comparatively tiny if they did - for the same

reason that contribution does not work well as a theoretical basis for property sharing or

alimony. The market value of services is thought not to capture the true value of

romantic companionship, but what makes a court think that "half the value of all property

accumulated” appropriately captures that value? The reason these implicit contracts are

not readily dismissed as absurd is because the prevailing law sets the prevailing

understanding of what people might expect to give and get in a relationship. If we

eliminated state-imposed property sharing at divorce, would any court really believe a

plaintiff who pled the existence of an oral or implied contract to share half of the

income ${ }^{189}$ Why would anyone make that contract if it wasn’t the prevailing legal

norm $?^{190}$

Here, it is worth noting that although the last 40 years show striking changes in

the ways families are created, function and re-organize, those changes reflect average

whether individual or combined ... [while] plaintiff would . . . render her services as a companion homemaker, housekeeper and cook ....”

${ }^{188}$ In re Roccomante, 808 A.2d 838 (NJ 2002) (awarding ex-lover support for life after her paramour died).

189 There is a strong tension between the decreasing rigor with which some antenuptial agreements are reviewed, see Younger, supra note 175, and the increasing tendency of courts to be willing to find oral or implicit contracts in cases involving non-married cohabitants. If more and more people enter into contracts that involve much less than 50/50 sharing and if more and more courts uphold contracts in which the dependent spouse is left with little, then few courts are going to be willing to imply a contract for significant sharing between non-married cohabitants.

${ }^{190}$ As suggested above, perhaps we should do away with state-imposed sharing norms and the interdependence, reliance and expectation that it enables. In such a world, dissolution agreements involving shared assets would need to be explicit and in writing, so at to minimize the (inevitably norminfused) interpretive role of the courts. But the world in which we live now is clearly one in which interdependencies do develop. There is reliance and there is expectation. It is not at all clear that people would prefer to live in a society in which the only spousal obligations that arose, arose by virtue of explicitly negotiated agreement. The fact that only a small portion of marriages entered into involve prenuptial agreements suggests a strong aversion to such a norm. 


\section{HOMOGENEOUS RULES}

numbers. There are consistent and profound class differences. For the college-educated middle and upper middle-class, the traditional nuclear family does not seem nearly as anachronistic. Among the college educated who marry and have children, the divorce rate has receded to the level it was at before the technological and social changes that were supposed to have changed everything. ${ }^{191}$ Higher socio-economic status is correlated with older age at first marriage, greater likelihood that cohabitation will lead to marriage, lower rate of cohabitation disruption, lower rate of first marriage disruption, higher probability of remarriage and lower probability of remarriage disruption. ${ }^{192}$

Education has become the great divider. Education is now a better predictor of who one will marry than is religion. ${ }^{193}$ This may be in part because college graduates can most easily reap the benefits of marriage as an income-pooling device, ${ }^{194}$ though wives in college educated couples contribute less to household income than wives in any other demographic group. ${ }^{195}$ College-educated couples are also the most likely to have significant property to distribute and the most likely to have a particularly gendered division of labor. ${ }^{196}$ In other words, the women most helped by the 50/50 divide are the

191 CAHN AND CARBOnE, supra note 18 at 39. ("The college-educated, who postpone childrearing until the parents achieve a measure of financial self-sufficiency and emotional maturity, have become more likely to marry and less likely to divorce than the rest of the population, with two-parent families that remain intact, replicating the statistics that existed before no-fault divorce, the pill, and legalized abortion.” )

192 CDC, Cohabitation, Marriage, Divorce and ReMarriage in the U.S, supra note 11 at 30-31.

193 CHERLIN, supra note 7 at 178-79.

${ }^{194}$ Id. For people on various forms of state support (TANF payments, food stamps etc.), the gains from marriage can be significantly less because income-testing and eligibility rules produce a taxation rate for marginal money earned that is much higher for the least wealthy than the most wealthy. Sara McLanahan, Diverging Destinies 614, 41 DEMOGRAPHY 607, 616 (2004). (Any economic advantage gained by adding an additional household member's income can be readily offset by decreasing eligibility for government benefits).

${ }^{195}$ Wives married to college-educated men contribute, on average $26 \%$ of household income. Wives married to husbands with less than a high school education contribute $29 \%$. Wives of high school graduates or husbands with some college contribute $33 \%$ to household income. New Economics, supra note 15 at 16 .

${ }^{196}$ See Baker, supra note 99 at 607 (college and professionally educated women, who are likely to be the most wealthy, are disproportionately likely to work significantly less than their husbands.) 


\section{HOMOGENEOUS RULES}

ones people might have thought would need it least, those with college educations or better, who once had or still have solid jobs and who, when compared to their class counterparts of forty years ago, are much better able to take care of themselves. Marriage really matters to these women.

\section{Alimony}

Alimony is by far the least formulaic of all of the family law obligations. It is also the most theorized. These points may be related. Widely followed rules, regardless of their theoretical justification, breed their own legitimacy. Normativity follows functionality and consistent and efficient rules become legitimate by virtue of their consistent and uniform application. This is just beginning to happen with alimony though. For most of the last 40 years, the legitimacy of alimony has been consistently questioned. $^{197}$

The first question one might ask is why. As most scholars agree, no one has ever developed a sound theory for distinguishing alimony from property division. Many state statutes provide comparable lists of factors to be considered for property division and alimony. ${ }^{198}$ The ALI states that the "policy issues involved in formulating criteria governing entitlement to alimony are largely indistinguishable from those that govern entitlement to an enhanced share of marital property.”199 In 2002, June Carbone wrote "we are no closer to determining what purpose the distinction between property division

\footnotetext{
${ }^{197}$ See supra notes 92-100 for list of articles explaining the theories of alimony.

198 Compare 750 ILCS 5/503(d) (distribution of marital property) with 750 ILCS 5/504 (maintenance). Many other states, including New York, Pennsylvania , Massachusetts, New Jersey, Alabama, and Nebraska, to name just some, have comparable lists of factors.

199 ALI PRINCIPLEs, supra note 67, § 4.09, Comment d, p. 736.
} 


\section{HOMOGENEOUS RULES}

and alimony should serve.”200 The 50/50 property distribution has been easily implemented and notwithstanding the above critique, accepted. Alimony rules have not.

\section{Backstop ?}

One role alimony has served, either on purpose or by default, is as a kind of backstop or "residual remedy, a grab-bag into which claims are put when they cannot be cast as child support or property allocation.”201 The attraction of such a backstop is not surprising given the problems described. Because of the relative importance that the child support guidelines pay to the marginal expenditure principle (and its protection of the non-custodial parent), the child support guidelines leave children from households in which their two parents earn very different amounts living at a standard considerably below the marital standard of living. ${ }^{202}$ An alimony award can help raise that standard of living. Because the property distribution rule usually fails to include the accumulation of human capital as an asset capable of being divided, spouses who invested in relationships with someone who was accumulating the human capital to enable him to be wealthy later in life are often entitled to only a small portion of that wealth. Alimony awards can provide those spouses with more. Providing a backstop because the mechanisms for determining other forms of family obligations are inadequate hardly seems like a legitimate source of obligation though.

\section{Compensation?}

While acknowledging that alimony awards serve this residual function, the ALI coins a new term for the awards that were originally known as alimony. It calls them “compensatory payments” and claims that they are to remedy "unfair loss allocation” that

\footnotetext{
${ }^{200}$ Carbone, supra note 88 at 54).

${ }^{201}$ Ellman, supra note 94 at 810.

202 See supra 119 ; ALI PRINCIPLES, supra note 67, §3.05, Comments p. 440.
} 


\section{HOMOGENEOUS RULES}

may occur at a marriage's dissolution. To its credit, unlike most of the states and counties that are currently devising alimony guidelines, the ALI tries to articulate a theory for alimony. But it is not clear that it succeeds. Why does a spouse need to be compensated with alimony if she is getting property? Her $50 \%$ share of property is hers by virtue of the marriage. Why doesn't the property cover her loss? She has lost the marital standard of living, but why is she entitled to it? As analyzed above, theories of expectation inevitably reduce to questions of fault ${ }^{203}$ and theories of reliance inevitably reduce to unanswerable questions. ${ }^{204}$

\section{Explanation}

The confusion surrounding these questions has clear costs. Without sufficient guidance on what an award might be, many women - even those in fairly long-term marriages - forego even attempting to secure alimony because bargaining for it is too difficult. $^{205}$ Alimony also tends to consume more court time than other litigated family law obligations. ${ }^{206}$ The states and counties developing guidelines seem more concerned with these costs than with the theoretical basis for an alimony award.

What is emerging as salient in the places implementing alimony guidelines are two variables, length of marriage and earning differential. The proposed ALI “compensatory payments” consider these variables, as do almost all of the formulas

\footnotetext{
203 See supra text accompanying notes 88-90. (both spouses cannot live at the marital standard unless there is significant unused excess). To suggest that one spouse is entitled to such a standard is to suggest that the other spouse is not and that ineluctably requires a rejection of the earner's priority principle and /or an inquiry that is based on some concept of fault as the basis of entitlement. See Carbone, supra note 88 at $74-$ 75.

${ }^{204}$ See supra text accompanying notes 9293. The rehabilitation standard, a core part of the no-fault reform era changes, used a reliance idea. But to determine reliance, one needs some sense of what the alternatives might have been so that one can determine what a party might have lost by relying. In a long term marriage, assessing what those alternatives might have been so many years before is extraordinarily difficult.

${ }^{205}$ Elgin, Alimony Guidelines: Is It Time, 83 MD. B J 46.

${ }^{206}$ Ellman. supra note 94 at, 813.
} 


\section{HOMOGENEOUS RULES}

currently used by individual judges and counties. By incorporating these two variables, the formulas are likely to protect the ex-spouse most likely to garner the public's sympathy, a traditional spouse from a long-term marriage, who dedicated herself to nonremunerative activities and who has grown accustomed, over a long period of time, to the elevated living standard that her husband could provide. The empirical evidence tells us that this spouse is much less likely than her younger counterpart to initiate a divorce and less likely to marry again quickly. ${ }^{207}$ Alimony, therefore, may seem particularly appropriate.

Again, though, it is easy to imagine factual scenarios in which this divorcing spouse would not garner much sympathy. What if she had given up on the relationship 10 years before it actually dissolved and he kept trying to make the relationship work? What if she had as many affairs as he did? What if her spending patterns account for the relative lack of marital property because she has already consumed so much marital wealth? What if he wants to quit his job and just relax for a while, but she is does not want to lose her lifestyle, so she leaves - probably entitled to alimony. Judges resist making distinctions based on these factors, apparently because they feel increasingly uncomfortable making the moral judgments necessary to distinguish between these claimants. And it is not clear that the public at large would be comfortable with judges making those judgments. With so much diversity of opinion on what constitutes appropriate marital commitment, how should the law decide if those commitments have been met?

${ }^{207}$ Carbone,supra note 88 at 65 . 


\section{HOMOGENEOUS RULES}

Formulas avoid particularized moral line drawing, though the alimony formulas drafted to date derive from originally discretionary judgments. The charge of the county in Maricopa County, Arizona to its commission on alimony reform is particularly noteworthy in this regard. The county asked technicians to design formulas that reflect average current alimony awards, rather than design formulas that define alimony obligations. ${ }^{208}$ Current practice derives from the decisions that judges currently make. Those decisions are guided, to the extent they are guided, by the various factors listed in the statute, which gives judges discretion. The experience of the Massachusetts judiciary is comparable. Judges derived their own formulae, based on their own prior decisions, which had been derived from the list of discretionary factors. ${ }^{209}$ Judges are fed up with those factors, but grant the factors at least enough legitimacy to act as the basis of a formula that will then set a more transparent reliable norm.

If alimony formulas come to be used and perceived as child support formulas are, few people will bother to understand the alimony models or the theories of obligation on which they are based. Judges will just apply them. Presumably, in such a world, technicians could substitute arbitrary numbers for any determination of average alimony award and the reformers would accept them as long as they did not strike them as too outlandish. With such a rule, parties would have a firmer norm around which to bargain and it is likely that alimony would be demanded more predictably, determined more reliably and consume less court time. Parties would understand what awards were likely to be, even if they did not understand what the awards were meant to represent. As with

\footnotetext{
208 The Commission was tasked with designing guidelines that would "reflect current practice more than set norms for it.” Ellman, supra note 94 at 811.

209 See supra note 105.
} 


\section{HOMOGENEOUS RULES}

child support and property, what would matter is a rule and an arbitrary one could easily work just as well as the current methodology.

\section{Defending the Arbitrary}

The foregoing analysis establishes that the rules governing family obligation are not based on decades of collective wisdom or moral consensus. They are mostly arbitrary. They are used either without relying on any theoretical base or by relying on a theatrical base that is likely controversial. For child support, the average marginal expenditure methodology upon which all the child support formulas are based relies on a 2 parent family household norm that is contested at both a descriptive and prescriptive level. And there is little coherence in the set of rules that determines who counts as a parent for obligation purposes. Comparably, the 50/50 distribution rule for marital property, though often presented as neutral and/or intuitively fair can be readily criticized as neither. Indeed, it represents a particular normative view of marriage and it does not render intuitively fair results in many situations. The emerging alimony formulas are perhaps the most transparently arbitrary. In essence, the reform commissions have said "Bring us some algorithms. We don't even want a theory for why they are appropriate.”

When evaluated contextually, however, this increasingly acontextual system of family law obligation is eminently defensible. It is also a logical outgrowth of a world in which diverse family forms proliferate and social acceptance of that diversity grows stronger. The very same social forces that make the formulae seem anachronistic and idiosyncratic make them necessary. 


\section{HOMOGENEOUS RULES}

\section{A. Child Support}

Contemporary child support guidelines seem anachronistic because they so completely rely on a biological family norm that so often does not and often never did exist for the parties subject to the guidelines. Recent scholarship calling for a reevaluations of how the law grants parental rights seems to be advocating for a legal family law regime that recognizes how rare that biological family form is. The scholarship advocates more discretion so as to afford the law more freedom to evaluate all the contexts in which families arise. ${ }^{210}$

Attention to context is what the law allowed before Congress mandated child-support formulas, however. ${ }^{211}$ Congress mandated formulas because it was concerned about how few resources were available to children through child support. The government was spending more money supporting children because changing demographics were making it increasingly likely that children would be living in households without their fathers.

Because there was so much money to collect from so many different people in different situations, policy makers had to be concerned about implementing a resource redistribution system that was clear, easy-to-apply, and widely applicable. More and more fathers were never parties to a divorce action. More and more fathers now lived with new families. More and more fathers were harder to track down. The time and money spent paying attention to all those contexts would inevitably detract from children's ability to get resources quickly. Thus, not surprisingly, policy makers produced formulae that were overbroad, acontextual, and riddled with hidden value choices. The formulas work not because they evaluate obligation fairly or accurately, but

\footnotetext{
${ }^{210}$ See supra notes 32-36.

211 See supra text accompanying notes 60-62 (explaining why Congress mandated that states develop child support guidelines)
} 


\section{HOMOGENEOUS RULES}

because they provide quick, stable numbers. With so many children and adults dependent on child support, a system that works becomes critical.

As suggested above, a more graduated formula system might be better able to capture the degrees of parenthood that seem prevalent today, but the more sensitive the formula was to context, the less well the system would work. A payor who wanted a lesser obligation could argue that there is a new parent in the family who should share the obligation. The more parents there are, the greater the chances of some adult experiencing a change of circumstances that might necessitate altering the child support allocation. All such dilemmas would take time and resources to adjudicate. They would also involve inquiries into the realities of the children's and parents' lives.

These are just some of the questions a court would need to address: Has an adult developed a sufficiently important relationship with a child for that relationship to warrant the imposition of obligation? Who's views about the relationship should count? The child's? The potential obligor? A current obligor who may know nothing about the potential obligor, but has much to gain from someone else being obligated? How should a judge allocate responsibilities between obligors? What if one obligor already has outstanding duties to another set of children? Should the formalization of the parental obligation to either set of children matter or just the reliance of the children? What about the reliance of another parent? How many other parents? When is such reliance reasonable? What if one set of children find a new source of support, who should enjoy the windfall of that new support, the children or the obligor? Should the obligor's income or parenting philosophy or intent to parent be at all relevant? 


\section{HOMOGENEOUS RULES}

These are very messy questions. A parent and/or a child eager to secure and keep resources flowing might strongly resent how much time it took to answer the questions, how invasive the process of answering would be, and how many resources the whole process would drain. An award derived from a formula based on a vanishing or arbitrary norm might be much preferred.

B. Property Distribution

A comparable story can be told about marital property distribution rules. The very forces that make the 50/50 rule seem too rigid, make it increasingly attractive. The sheer number of divorces, particularly the number of divorces that settle without seeing a courtroom, make the advantages of a bright line rule paramount. The parties know the law. There is little to fight about. The empirical work done on mediation confirms that most parties mediate property distribution arrangements that are comparable to judicial awards. ${ }^{212}$

Just as important, the increasing discomfort (and possible constitutional difficulty) with using family law to enforce marital and sexual norms in the 1960s and 70s created a countervailing need for financial norms. When divorcing parties had to prove fault, the party least anxious for a divorce had more bargaining power to secure an adequate property settlement. For instance, if the party least anxious for divorce really wanted the house, she could often get it in exchange for a no-contest divorce. Judges then, as now, often only cursorily reviewed the divorce settlement because the parties presented it to the court as a fait accompli. If the party most anxious for divorce held no property, she

${ }^{212}$ See supra note 68. 


\section{HoMOgENEOUS RULES}

could be left with nothing, but her financial predicament could be justified because, as far as the law was concerned, by wanting the divorce, she was blameworthy.

With the advent of no-fault divorce and the law's decreasing willingness to enforce moral and sexual norms, two problems emerged. First, the parties themselves, if they still wanted to avoid the courtroom, had virtually no rules to guide them in settlement. Second, the law needed to be much more concerned about the party left with so little property. She had done nothing wrong. Her spouse was free to divorce her at his will and, even if she was the one eager for divorce, the law was now unwilling to call her blameworthy. How should the law decide what she should get?

Many wives now contribute financially to the household. ${ }^{213}$ Many also do not, or they contribute little, particularly when children are small. ${ }^{214}$ Many wives do less household work than they used to. ${ }^{215}$ But most wives still do much more than their husbands. ${ }^{216}$ Many wives have a work history that parallels their husbands, but most likely on a different plane, earning less money. How should judges evaluate all the different ways in which married couples now choose to construct their lives?

The long list of factors that the original equitable distribution statutes provided was probably meant to help address these problems. The factors gave judges, and to a certain extent the parties, something on which to base a property settlement. But the growing heterogeneity of families and the social acceptance of that heterogeneity made the application of those factors all but lawless. As one scholar suggested at the time

\footnotetext{
${ }^{213}$ Zoe Savitsky, Recent Developments: Inertia and Change: Findings of The Shriver Report and Next Steps, 25 BERKELEY J. GENDER L. \& JUST. 172,174 (Spring, 2010).

${ }^{214} I d$. at 175.

${ }^{215}$ Suzanne Bianchi, John Robinson, Melissa Milkie, Changing Rhythms of American Life 90 (Russell Sage Foundation, 2006).

${ }^{216} I d$.
} 


\section{HoMOgENEOUS RULES}

"what consistently distinguishes [equitable distribution statutes] from their predecessors is not that they are more equitable, but that they are more unpredictable.” ${ }^{217}$

It is common for social commentators of all sorts to mock the uniformity of American post-World War II, “Leave It To Beaver," family structure, but those rigid norms made the law's job much easier. People who acted in accordance with the norms needed to be protected. Those who deviated did not. Today, with so much deviation and so little normativity, it is much less clear who needs to be protected and why. A blanket property distribution rule avoids the need to make distinctions between kinds of couples. Everyone is entitled to the same division of property because people are no longer comfortable with the law making distinctions between kinds of marriages.

A regime that paid much less attention to marital status would be a regime in which people's post-relationship obligations would be determined by judicial evaluation of the relationship, marital or not. ${ }^{218}$ Was it the kind of relationship for which the law should impose post-relationship obligation? What made it that kind of relationship? Should a judge assume that the parties meant to share? Why? If the law abandons any presumption of sharing, should it entertain claims pertaining to reliance or dependence? Does relative dependence matter or only absolute dependence? Does longevity of the relationship matter? Why? Would we trust courts to arrive at remotely comparable assessments in comparable cases? Many people might rather a world in which their obligations and entitlements were set simply by the arbitrary rules of marriage to a world

\footnotetext{
${ }^{217}$ Glendon, supra note 80 at 1556.

${ }^{218}$ Alternatively, courts might rely on explicit written relationship contracts, but drafting those contracts does not appear to be a relationship activity that very many people wish to engage in at all. See supra note 190.
} 


\section{HOMOGENEOUS RULES}

in which they had to worry about all of these invasive questions being asked of and about them.

\section{Alimony}

The way in which alimony formulae are currently being designed and implemented throughout the country suggest yet another version of the same story. The collapse of social and marital norms leave judges without a normative yardstick by which to measure entitlement. The intuitive understandings of fairness that led judges to refuse to abandon alimony altogether, ${ }^{219}$ provide sufficient justification for a blanket system of entitlement that pays heed to length of marriage and income differential - though nothing else. The formulas that Bar Committees and judges are implementing now eschew the various theories of entitlement that academics have offered. ${ }^{220}$ Instead, they emphasize predictability. Fairness will follow not from moral consensus about entitlement but from a formula. The norm will be reliable because it will be reduced to numbers. What the practitioners of family law are demanding are rules they can litigate and settle by. They are willing to cede the responsibility for determining when and why family obligation arise to legal status distinctions and arbitrary formulas because of the disadvantages associated with a more sensitive system of justice.

D. Summary

The moral frameworks and normative structures upon which the law used to gauge family obligation have all but disappeared. Formulas have taken their place and judges, lawyers and litigants all seem remarkably content with that formulaic system. The

\footnotetext{
${ }^{219}$ See supra text accompanying notes 92-94. (The move to no-fault was accompanied by a move to eliminate alimony so that the spouses could "go their separate ways," but many judges refused to deny alimony to women who had invested heavily in their families but had few prospects of meaningful employment.)

220 See supra notes 103-105.
} 


\section{HOMOGENEOUS RULES}

willingness of judges and lawyers to accept and even encourage these formulas says something striking about the frustration with flexible standards.

In other areas of the law, criminal sentencing for instance, judges have strongly resisted guidelines. Like the child support guidelines, the Criminal Sentencing Guidelines were instigated by Congress to be implemented by judges in order to bring rationality and consistency to a discretionary process. Judges bemoan the Criminal Sentencing Guidelines as ill-conceived and unjust and far too insensitive to context. ${ }^{221}$ In that area, judges value discretion and seem to have faith that discretion renders fairer results. Not so with family law obligations.

Lawyers are comparably accepting of the guidelines, even though they have an economic interest in more discretionary standards. Domestic relations lawyers, like most lawyers, get paid by the hour. ${ }^{222}$ In theory, the less certain the rules, the longer it takes to resolve a case. Yet lawyers have been as big a part of the task forces for alimony reform as judges. ${ }^{223}$ Lawyers have not pushed back hard against the 50/50 division rule. The yearning for consistency and predictability appears strong enough to overcome both institutional and economic interest.

Without formulas, judges confront the panoply of questions. Family members and their lawyers strain to answer them. Who is a parent? Why? How much should this kind of parent have to pay? Why? Were these two people a unit? Why? How much of a unit and for what? What is a fair resolution? Why? Judges and lawyers have expressed

\footnotetext{
${ }^{221}$ Nathan Greenblatt, How Mandatory Are Mandatory Minimums? How Judges Can Avoid Imposing Mandatory Minimum Sentences, 36 AM. J. CRIM. L. 1 (Fall, 2008).

${ }^{222}$ Contingency fees have been struck down in the divorce context as against public policy. See HARRIS, TEITELBAUM, CARBONE, supra note 57 at 754.

${ }^{223}$ The ALI is made up of both practicing lawyers and legal academics. The American Academy of Matrimonial Lawyers, which developed their own guidelines, see supra note 102 is made up only of practicing lawyers.
} 


\section{HoMOgENEOUS RULES}

an unmistakable desire to avoid these questions. And most litigants probably want to avoid them as well. Not only are they invasive and time-consuming. They are expensive. Only a tiny percentage of the millions of people affected by the law of family obligation have the resources or desire to litigate fully the scope of their obligations and entitlements. Thus, despite how easy it is to criticize and even mock the formulas by which the law assesses family obligation, a formulaic system is quite easy to defend as well. Diverse family form and the social acceptance of that diversity make attention to context extremely onerous.

\section{Ramifications}

\section{A. The Law’s Role in Defining Family}

The analysis presented above suggests that, whatever different people’s understandings of their own kinship networks, the law does a prodigious amount of work in defining family. For instance, the 50/50 distribution rule plays a formative role in the substantive definition of marriage. It makes the marital commitment substantial. It provides insurance for those spouses who choose to become financially dependent. It facilitates the division of paid and unpaid labor. It rejects the earner's priority principle and the contribution principle as inconsistent with marriage. It sets a default rule that allows and encourages couples to think of themselves as an entity. Those who believe that fairness in their marriage should mean something other than 50/50 have the burden of drafting and implementing a prenuptial contract that will say so. 


\section{HOMOGENEOUS RULES}

The vast majority of people getting married today may be ignorant of this definitional work done by the 50/50 rule because they neither sign a prenuptial agreement nor think much about the financial rules that accompany marriage. ${ }^{224}$ But the divorce rate suggests that a huge portion of people who may have been ignorant of the $50 \%$ rule when they entered marriage, live by it later when they divorce. The failure of divorcing parties to protest the rule, and anecdotal evidence of what divorcing parties feel entitled to, suggest that people really are comfortable with the law doing that definitional work. Divorcing parties routinely walk into their attorney’s office saying "I only want what is fair.” ${ }^{225}$ But they ask their lawyer what is fair. Their lawyer tells them what the law is. The law says fair is 50/50. The formula defines the fairness and in doing so it helps define what marriage is. ${ }^{226}$

Comparably, few parents contest the law’s imposition of a percentage-of-incomerule for child support purposes. At the extremes of poverty and wealth the guidelines sometimes give way to context, and the different formulas provide some modification to the exact percentage, but for the most part it is accepted. As suggested above, there is little reason to think that different percentages would encounter much resistance.

Precious few people understand where the marginal expenditure figure comes from anyway. Litigants, judges, lawyers and scholars simply accept the law’s role in defining parental obligation. In doing so, they accept the law's role in defining parenthood.

\footnotetext{
${ }^{224}$ Frantz, supra note 185 at 272

${ }^{225}$ Various conversations with Chicago area family law attorneys (Fall, 2010)

${ }^{226}$ It is possible, though I think unlikely, that when they ask for what is fair, litigants are instead saying "I understand the need for a clear default rule in this context because litigation is expensive and I'm probably better off with a clear default than with an murky standard which might allow me to end up paying less.” Most divorcing parties are much less likely than most people contracting in a commercial context to be familiar with the advantages of clear default rules and there is abundant evidence that divorce is often so emotionally difficult that parties find it difficult to think clearly. See Thomas Carbonneau, A Consideration of Alternatives to Divorce Litigation, 1986 U. ILL. L. REV 1119, 1126 (1986).
} 


\section{HoMOgENEOUS RULES}

The comprehensive, non-discretionary obligations imposed by formulae avoid the need for invasive, expensive and time-consuming questions, but they also cede to the law a critical role in defining what family means. It seems, then, that we have relinquished a great deal of power to the state. In a world with these formulae, obligation does not come from context or agreement or reliance. It comes from state recognized status. A parent pays $20 \%$ of his or her income in child support because that is how the law defines parenthood, just as the law declares that marriage requires an equal sharing of all either party earns during the marriage.

\section{B. Constitutional Claims}

Recognizing the primacy of the state's role in defining the family in this way may simultaneously weaken and strengthen different constitutional claims to family status. Those who argue that people have a fundamental right to either marital or parental status must reckon with how much definitional work we have ceded to the state. If the state has so much authority to define what marital property is and how much of it has to be divided, why shouldn't the state also decide who should be entitled to that division? How could someone have a fundamental right to a marital status that the 50/50 distribution rule helps define, when the state can easily change that 50/50 rule (quite possibly without anyone even protesting) tomorrow? If the state decides who is a parent and who is not for purposes of child support and if the state can define the obligations of that parental status based on arbitrary declarations of appropriate responsibility, how can someone have a fundamental right to parental status?

There are answers to these questions - and ways of salvaging some sort of fundamental right to family status. Cass Sunstein, David Meyer and myself have all 


\section{HOMOGENEOUS RULES}

suggested that fundamental rights to family status are a function of social norms that give those statuses meaning, meanings that exist apart from any strict legal definition. ${ }^{227}$

The ability to conform to those social norms has expressive value that perhaps the state must honor. But social norms are not fixed by either time or geography. Social norms regarding marriage and parenthood can vary across time and region and the law’s abdication of much of its role in policing moral and sexual norms in marriage may make it more likely that norms will vary greatly across time and region. This does not bode particularly well for fundamental rights claims to family status at a national level.

By the same token, recognizing the primacy of the state's role in defining family may strengthen equality claims to family status. If the family is a state, not a private or pre-legal institution, then the need to treat all citizens equally with regard to that institution increases. The state may be able to define what marriage and parenthood are, but equality jurisprudence dictates that everyone be given equal access to those institutions.

To date, one state supreme court and one federal district court have found that same sex couples have a fundamental right to marry. ${ }^{228}$ The other state courts that have

\footnotetext{
${ }^{227}$ Cass Sunstein has suggested that the fundamental right to marry is best conceived of as an expressive right, but "the expressive benefits of marriage are contingent on a particular constellation of social norms; there is nothing inevitable bout them.” Cass Sunstein, The Right to Marry, 26 CARD. L. REV. 2081, 2098 (2005); David Meyer has argued that the constitution treats parental status as it treats property rights. The state is free to define a vast expanse of property rights and to tinker with them at will, but it is not free to alter those rights so substantially that property loses its contemporary meaning. David D. Meyer, Partners, Caregivers and the Constitutional Substance of Parenthood, in RECONCEIVING THE FAMILY supra note 87 at 47, 61. I have argued that the constitutional rights to both marital and parental status reflect expressive values implicit in the label "married" and "parent," but that those rights are necessarily cabined by the social meaning of both marriage and parenthood. Baker, supra note 139 at 132.

${ }^{228}$ In Re Marriage Cases, 193 P 2d 384, 399 (2008) found that gays and lesbians had both a fundamental right and an equality right to marriage. These constitutional conclusions with regard to marriage per se were substantially overturned by the same California Supreme Court in Strauss v. Horton, 207 P3d 48, 76 (Cal., 2009), which upheld Proposition 8 and declared that whatever constitutional rights gays and lesbian couples were entitled to under fundamental rights analysis were satisfied with the conferral of Domestic Partnership status. In Perry v. Schwarzenegger, the federal district court found Proposition 8
} 


\section{HOMOGENEOUS RULES}

found in favor of same sex marriage have relied on equality doctrine. The analysis

presented here suggests that equality doctrine holds more promise and that the U.S.

Supreme Court cases suggesting that there is a fundamental right to marital status should

be read narrowly. ${ }^{229}$

\section{Family Construction Claims}

As indicated in Part I, much recent family law scholarship argues that the law of the family needs substantial re-orientation. In various forms, different authors have argued against the normativity of any family status. According to these views, the law should play a minimal if any role in defining or privileging family forms. Instead, the law should respond to emotional and familial attachments as lived or chosen. The analysis in this article forces a question on this line of scholarship: Should there be any legally enforceable family obligations?

Consider marital property distribution. If the time has come to break down the conventional normativity of domestic relations law, we should be wary of a ubiquitous

unconstitutional under both fundamental rights and equality analysis. The Supreme Courts of Iowa, Varnum v. Brien, 763 NW2d 862, 899 (Iowa, 2009) and Connecticut, Kerrigan v. Comm’r, 957 A.2d 407, 479 (Conn. 2008) decided in favor of same sex marriage using an equality analysis not a fundamental right to marriage analysis. The Supreme Judicial Court of Massachusetts collapsed the two doctrines completely and used a rational basis test to find in favor of same sex marriage, Goodridge v. Dep't of Pub Health, 798 NE2d 941, 969 (Mass. 2003). Thus, it would be quite inaccurate to say that the Massachusetts court found a fundamental right to marry.

${ }^{229}$ Loving v. Virginia, 388 US 1 (1967) (finding that miscegenation statutes were racially discriminatory and finding a fundamental right to marry); Zablocki v. Redhail, 434 US 374 (1978) (striking down a Wisconsin statute under the because it inhibited the right to marry under the Equal Protection clause; Turner v. Safely, 482 U.S. 78 (1987) (state prison cannot bar a prisoner from marrying because doing so violates the right to marry found in Zablocki). For instance, the marriage that the Supreme Court declared that Mildred Loving had a fundamental right to in 1967 included no rights to be protected from marital rape or to sue her spouse in tort and no obligation to support her husband if they separated. Today, she would have rights to all of that because the prior marital rules and norms have been struck down as antithetical to modern notions of marriage and gender equality norms. See People v. Liberta, 474 NE2d 567 (NY 1984) (striking down the marital exception to rape law as irrational); Burns v. Burns, 518 So.2d 1205 (Miss. 1988) (finding the common law doctrine of interspousal tort immunity to be inconsistent with constitutional and statutory notions of gender equity); Orr v. Orr, 440 US 268 (1979) (striking down as violative of equal protection a legislative judgments that husbands but not wives should be responsible for alimony). So what is it that Mildred Loving had a fundamental right to? It was not the understanding of marriage that we have today. 


\section{HOMOGENEOUS RULES}

50/50 divide. If the law should afford more respect to individuals' decisions to structure their home life as they choose, we should question a blanket rule for redistribution of resources. The demographic changes of the last 40 years arguably require much more attention to context and detail so that courts can evaluate how much sharing a couple actually did, how much interdependence existed between them, how much monetary or nonmonetary contribution each spouse made.

Those are exactly the kinds of details that have been dismissed as irrelevant or impossible to evaluate by the courts, however. The people responsible for enforcing the law of family obligations have rejected a system in which obligation arises from context. It is too unwieldy. But if obligation should not arise from context because the courts are institutionally incapable or unwilling to evaluate context, nor from status because the state should not impose status, from whence should family obligation arise?

Without going into detail, some scholars have suggested that decreasing the state's role in defining the family will require an increased state role in meeting dependency. $^{230}$ There is an irony or perhaps just a strong dose of utopian thinking here: The way to decrease the state's power in setting family norms is to increase the state's financial involvement in people’s lives. The Supreme Court has not been very receptive to this kind of argument before, finding that the state has a right to follow its money. ${ }^{231}$

\footnotetext{
${ }^{230}$ Murray and Ristrophe, supra note 40 at 140. ("Though we cannot develop the argument at length here, we believe a disestablishment perspective is consistent with substantial public financial support for caregiving in families.”)

${ }^{231}$ Wyman v. James, 400 US 309, 319 (1971) (Finding that a social worker inspection of an aid recipient's home was not a search within the meaning of the Fourth Amendment because "[o]ne who dispenses purely private charity naturally has an interest in and expects to know how his charitable funds are utilized and put to work. The public, when it is the provider, rightly expects the same. It might well expect more, because of the trust aspect of public funds, and the recipient, as well as the caseworker, has not only an interest but an obligation”).
} 


\section{HOMOGENEOUS RULES}

And it seems quite likely that if government were to take over all of the obligation to meet individual dependencies, our understanding of family membership would change.

In order to impose obligations, the law needs to determine entitlements and responsibilities. In the last 20 years, the law has moved toward a system in which those entitlements and responsibilities are determined from a distance, based on average numbers, normative theories of family and legal status distinctions. The cost of context has been adjudged too high. The analysis presented here raises doubts about whether we can have both a world in which the law enforces family obligations and a world in which the law does not privilege certain family forms.

\section{Conclusion}

This article's defense of the current formulaic system does not ineluctably mean that the current system should be defended. The arbitrariness of the current system is undeniable. Anachronistic and contested normative visions of parenthood and marriage permeate the legal treatment of family obligation. Without doubt, reformers could (and I think, in many instances should) tweak parts of this system. The law of parental obligation could develop a more logical means of determining what sort of commitment to parent should trigger responsibility. Models based on equivalence scales could be rejected in favor of more transparent, though perhaps less theoretical, baselines. The 50/50 rule for property distribution could be changed to a more proportional contribution rule. One can easily provide arguments in favor of all these changes, but it is unlikely that these types of changes will solve the basic over and under inclusiveness problems 


\section{HOMOGENEOUS RULES}

that result from determining family obligation based on pre-defined understandings of what families are and how they operate.

Thus, as the scholarship argues, more profound changes may be necessary. Perhaps the arbitrariness and contested normative ideals analyzed in this article should be more regularly highlighted so that they can be rejected. Perhaps the relevant players have gotten the cost/benefit analysis wrong: Judges, lawyers and litigants should be compelled to ask and attempt to answer the hard normative questions because in doing so they will allow the law to incorporate a more coherent, nuanced, framework for family obligation.

This article suggests that pushing the law to answer these hard normative questions will not be easy and for many people may not be desirable. However varied their own normative visions of family life, people may not want judges, lawyers and litigants asking formative questions about family composition at every opportunity. People may be willing to cede to the state the role of defining family status so that the law can reliably impose family obligation.

Sir Henry Maine famously prophesized that the trajectory of the law was one from status to contract, ${ }^{232}$ but despite the massive upheaval in both family life and family law over the last forty years, the salience of family status has grown more, not less important to the imposition of legal obligation. The flaws in this status-based system of obligation are obvious. Much less obvious is whether a system based on something other than status could effectively impose family obligations at all.

232 See R H Graveson, The Movement from Status to Contract, 4 Modern L. REv 261, 261 (1941)

(discussing Sir Henry Maine’s famous axiom). 